\title{
44. THE MAIN RESULTS OF ODP LEG 107 IN THE FRAME OF NEOGENE TO RECENT GEOLOGY OF PERITYRRHENIAN AREAS1
}

\author{
Renzo Sartori ${ }^{2}$
}

\begin{abstract}
The Tyrrhenian Sea is a land-locked basin which developed in an area previously occupied by both Alpine and Apenninic orogens. These formed, with opposed vergences, in several tectonic phases spanning from Upper Cretaceous to Tortonian. Basin generation started afterward and was accompanied by further deformations of the Africa-Adria-verging orogenic systems (Apennines, Calabrian Arc, Sicilian Maghrebids).

The recent drillings of ODP Leg 107 and previous geological and geophysical data indicate that the development of the Tyrrhenian Sea was complex during any kind of process (rifting, drifting, subsidence, magmatism, and margin tectonism). Except for weak evidences of a subsidence restricted to lower Miocene (in the Corsica and Sardinia Basins), rifting started in the whole basin in upper Tortonian times.

In the northern Tyrrhenian Sea (separated from the southern domain by an east-trending major lineament running at $41^{\circ} \mathrm{N}$ ) rifting migrated eastward with time and affected peninsular Italy (Tuscany), reaching to the present orographic divide of Northern Apennines in Pleistocene. This migration was accompanied by emplacement of magmatic bodies; the process did not produce severe crustal thinning of the area.

In the southern Tyrrhenian Sea, strong extension leading to severe crustal thinning was instead produced by a number of discrete, short-lived, rifting events. The first one affected the Cornaglia Terrace, that is the bathyal plain west of the R. Selli Lineament, between upper Tortonian and intra-Messinian times (DSDP/ODP Sites 132, 653, 654). It produced north-trending extensional listric faults that generated a deep Messinian basin in the Cornaglia Terrace. The intra-Messinian cessation of this event might be tentatively correlated with the first creation of oceanic crust, south of $40^{\circ} \mathrm{N}$, in the present southern bathyal plain.

East of the R. Selli Lineament and in the Vavilov Basin proper (north of $40^{\circ}$ ), a second rifting cycle was active during Messinian (upper?) to lower Pliocene (maybe including the G. margaritae Zone). During this period the region presently occupied by the oceanic Vavilov Basin turned from an emerged and eroded chain into a rifted margin (ODP Sites 652,656 ). Oceanic crust started emplacing in the Vavilov Basin just after this phase, around 4.3 Ma ago (DSDP/ODP Sites 373,655 ), roughly at the base of the $G$. puncticulata Zone (lower Pliocene). Drifting proceeded in a roughly symmetrical way at least up to $2.6 \mathrm{Ma}$ (ODP Site 651 ; end of the $G$. aemiliana Subzone of middle Pliocene). Ultramafic rocks were also emplaced nearby the accretion axis (ODP Site 651).

The upper Tortonian to middle Pliocene basin kinematics, driven by roughly north-trending listric faults, implies a chiefly east-west oriented transfer and transform fault system in the central Tyrrhenian Sea. As also indicated by the distribution of coeval magmatic bodies (volcanoes are mostly erupted along north-trending fractures), the dominant extensional stresses should have been in the meantime roughly east-west oriented. If correct, such stress pattern implies that the north Sicilian margin was at that time mostly affected by transform/transpressional tectonics.

From Messinian to middle Pliocene time a northward rift propagation (from the southern bathyal plain to the Vavilov Basin) is also implied, leading finally to the triangular shape of the oceanic area and possibly to an anticlockwise rotation of the south apenninic Tyrrhenian margin. Strong subsidence of the whole central oceanic domain also started in middle Pliocene, inducing a progressive flexing and/or a sudden downwarping of the Sardinia margin.

In upper Pliocene stretching phases were resumed, but they appear mostly confined to the southeast Tyrrhenian Sea. In the Marsili Basin new oceanic crust was emplaced starting in uppermost Pliocene (ODP Site 650). Extensional stresses once more affected the Tyrrhenian Basin, inducing the rejuvenation of former lineaments and the eruption of new volcanic edifices. The new stress pattern, however, appears rotated $20^{\circ}-30^{\circ}$ clockwise with respect to the pre-middle Pliocene one (from $\mathrm{N} 90^{\circ}-100^{\circ} \mathrm{E}$ to $\mathrm{N} 110^{\circ}-130^{\circ} \mathrm{E}$ ). The Pleistocene stress pattern implies transform motions more or less parallel to the strike of Southern Apennines and normal to the Calabria-Peloritanian arc. Meanwhile, calc-alkaline, shoshonitic, and high-K volcanism became important (Roman, Campanian, Aeolian provinces) and produced huge amounts of volcaniclastic materials discharged into the deep basins. Pleistocene basin subsidence was very strong not only in the Marsili Basin (ODP Site 650) but also in the entire Tyrrhenian area located east of the R. Selli Lineament (ODP Sites 651, 652, 656).

During the generation of the Tyrrhenian Sea, tectonic deformations produced two main arcs in the perityrrhenian orogens: Northern Apennines and Southern Apennines-Calabria-Sicily. They are separated by important transversal lines (Ancona-Anzio and Ortona-Roccamonfina) limiting the sector of Central Apennines. The two arcuate belts formed after Tortonian and followed different tectonic evolution and shortening history.

Within the external Northern Apennines, a piggy-back sequence of thrust units is recorded from Messinian to middle Pliocene, contemporaneous with graben/half-graben developments in the internal domains. By opposition, in the Southern Apennines, Messinian to middle Pliocene compressional tectonism appears more intense and is related likely to a more important anticlockwise rotation of the thrust units. In the meantime, the Central Apennines acts as the area where the two arcs cross, and so progressively accommodates their differences in rotation via important transversal, transpressional lineaments. This also partly induces the arcuate shape of Northern Apennines. The evolution of the two
\end{abstract}

\footnotetext{
${ }_{1}^{1}$ Kastens, K. A., Mascle, J., et al., 1990. Proc. ODP, Sci. Results, 107: College Station, TX (Ocean Drilling Program).

2 Dipartimento di Scienze Geologiche, via Zamboni 67, 40127, Bologna Italy.
} 
arcuate belts is mirrored within the Tyrrhenian Sea by both stronger crustal thinning in the southern basin and triangular shape of the oceanic domain of the central area (southern bathyal plain and Vavilov Basin).

After middle Pliocene times, deformation style is modified in both Northern Apennines and Southern ApenninesCalabria-Sicily. Within the Po Plain, the piggy-back motion of thrust units ceased, and more recent units evolved mainly in an overstep sequence. In the Southern Apennines, wrench-related structures appear more important than structures due to pure compression. Strong compressional deformations occurred mostly off the Ionian side of the Calabrian Arc, while in Sicily the post-middle Pliocene thrust fronts seem to have developed at high angles with respect to the previous structures. All these changes may be possibly related to the shift in rifting/drifting processes from the central to the southeastern Tyrrhenian Sea and to the accompanying change in extensional stress pattern which occurred at about middle Pliocene time.

As regards the style of deformations, in the external portions of the perityrrhenian orogens, we observe thrust fronts, thrust growth faults, enhanced subsidence, and unconformities/hiatuses bounding sedimentary cycles in satellite and foredeep basins. Again in the internal chains we observe sedimentary cycles bounded by unconformities/hiatuses in graben/half-graben structures. Syn-rift subsidence episodes in the Tyrrhenian Basin seem mirrored by the deposition of "postorogenic" sequences developing in the latter setting, and by enhanced subsidence in foredeep sectors, often accompanied by wrenching and by formation of clastic wedges along thrust growth faults, active in the interval.

Slowdown/cessation of rifting episodes, emplacement of oceanic crust and subsequent accelerated subsidence in the basin seem to be reflected in the sedimentary sequences of both internal and external chain domains by unconformities/ hiatuses, as well as by wrenching or rotation of thrust units and chain segments. Some of these sedimentary breaks may be caused by isostatic reequilibration (and eustatic) processes.

In a refined stratigraphic frame such as the one now available for Mediterranean upper Neogene, the development of the land-locked Tyrrhenian Basin can be seen then as a continuous process marked by a number of "events." Such events appear coeval inside the basin and along its peripheral orogens. However, they differ in style and amount of deformation depending on the changing stress pattern and on location of the tectonic source areas affected by crustal thinning and drifting phases. Such factors are in turn related to the progressive modifications and configurations occurring at the level of a subducting lithospheric slab, still presently recorded only under the southeast Tyrrhenian Basin. The evolution in time of this inherited and retreating slab may also be influenced by the location of the more stable elements of the evolving orogenic systems with respect to the motion of the larger plates interacting in the area (Europe and Africa/Adria).

\section{INTRODUCTION}

Drilling performed during ODP Leg 107, in addition to previous geophysical and geological data, has demonstrated that the Tyrrhenian basin started developing in Neogene times. The Africa-Adria verging orogenic systems bordering the Tyrrhenian domain in peninsular Italy (Apennines, Calabrian Arc) and in Sicily (Maghrebids), were also mostly formed in Neogene and Quaternary. Kinematically, the perityrrhenian tectonic accumulation areas, with thickened crust, could then be connected to the tectonic source areas represented by the Tyrrhenian basin with thinned to oceanic crust (Sartori and Scandone, 1985).

This paper first focuses on the main evolutionary steps of the basin, as deduced from available data, and then discusses some working hypotheses on how the basin evolution could be connected, spatially and temporally, to deformations occurring in the perityrrhenian orogenic systems (Patacca and Scandone, 1987; Sartori et al., 1987a).

\section{EVOLUTION OF THE TYRRHENIAN BASIN}

The Tyrrhenian Sea can be subdivided in two domains: the Northern Basin, shallower, with an articulated morphology; the Southern Basin, deeper, with large bathyal plains and isolated seamounts, both volcanic and non-volcanic.

\section{The Northern Tyrrhenian Sea (Fig. 1)}

The northern Tyrrhenian sector extends south of the Ligurian Sea to $41^{\circ} \mathrm{N}$, where a strong east-trending magnetic and tectonic lineament (Bolis et al., 1981; Wezel, 1985; Finetti and Del Ben, 1986) separates this domain from the southern Tyrrhenian Sea, characterized by extreme crustal thinning and by the presence of oceanic crust.

The north Tyrrhenian Sea does not exceed some 2,000 m of water depth and includes, from west to east: the Corsica basin; a system of north-trending ridges and valleys (the former emerging locally as the islands of the Tuscan Archipelago); and the Italian continental shelf (Fig. 1). The acoustic basement is mainly made of Alpine and Apenninic tectonic units (Colantoni et al., 1981a). The Alpine units, verging toward west-northwest, were emplaced essentially in pre-Oligocene times, and crop out in northeastern Corsica. In the so-called postorogenic basins (eastern part of the island) as well as in the offshore Corsica Basin, these units are covered unconformably by Burdigalian to Langhian sediments (Sartori et al., 1987b and references therein). After a hiatus encompassing part of the Miocene, a new sedimentary cycle started in upper Tortonian times. East of the Corsica basin, the north-trending valley and ridge system (locally marked by strong magnetic anomalies), corresponds to a domain of extensional tectonics superposed and cutting across previous thrust units showing an eastward (Apulian) vergence (Zitellini et al., 1986).

Industrial boreholes and comparison with land geology data indicate that these apenninic thrusts were deformed during a series of Burdigalian to Tortonian compressional events. The superposed extensional tectonics is supposed to be of upper Tortonian age in the central north Tyrrhenian, to become younger moving eastward. Extensional tectonism is contemporaneous with a series of magmatic bodies that are younger and emplaced at progressively shallower crustal levels toward the east (Marinelli, 1975). They are mostly granitic and granodioritic plutons dated at 9-7 Ma (upper Tortonian) in the westernmost sector (Capraia, Elba, Montecristo islands, and Vercelli Seamount; Savelli, 1984). Pliocene plutonic bodies occur farther east (Giglio island, $5 \mathrm{Ma}$ ) and magmatism changes to Plio-Pleistocene subvolcanic and effusive bodies in southern Tuscany, up to the late Pleistocene Mt. Amiata volcanics and the present-day Larderello geothermal fields.

Extensional tectonism and magmatism evolved then in the same way, starting in upper Tortonian and directly connecting the horst and graben system of the north Tyrrhenian Sea to the similar one developed in south Tuscany. The grabens of the latter area appear mostly asymmetrical, with master listric faults often facing the north Tyrrhenian basin (Bartolini et al., 1983).

\section{The Southern Tyrrhenian Sea (Fig. 1)}

South of the $41^{\circ} \mathrm{N}$ lineament, the Tyrrhenian Sea results from a more intense stretching, giving rise to a complex morphological setting, to a high water depth, and even to emplace- 


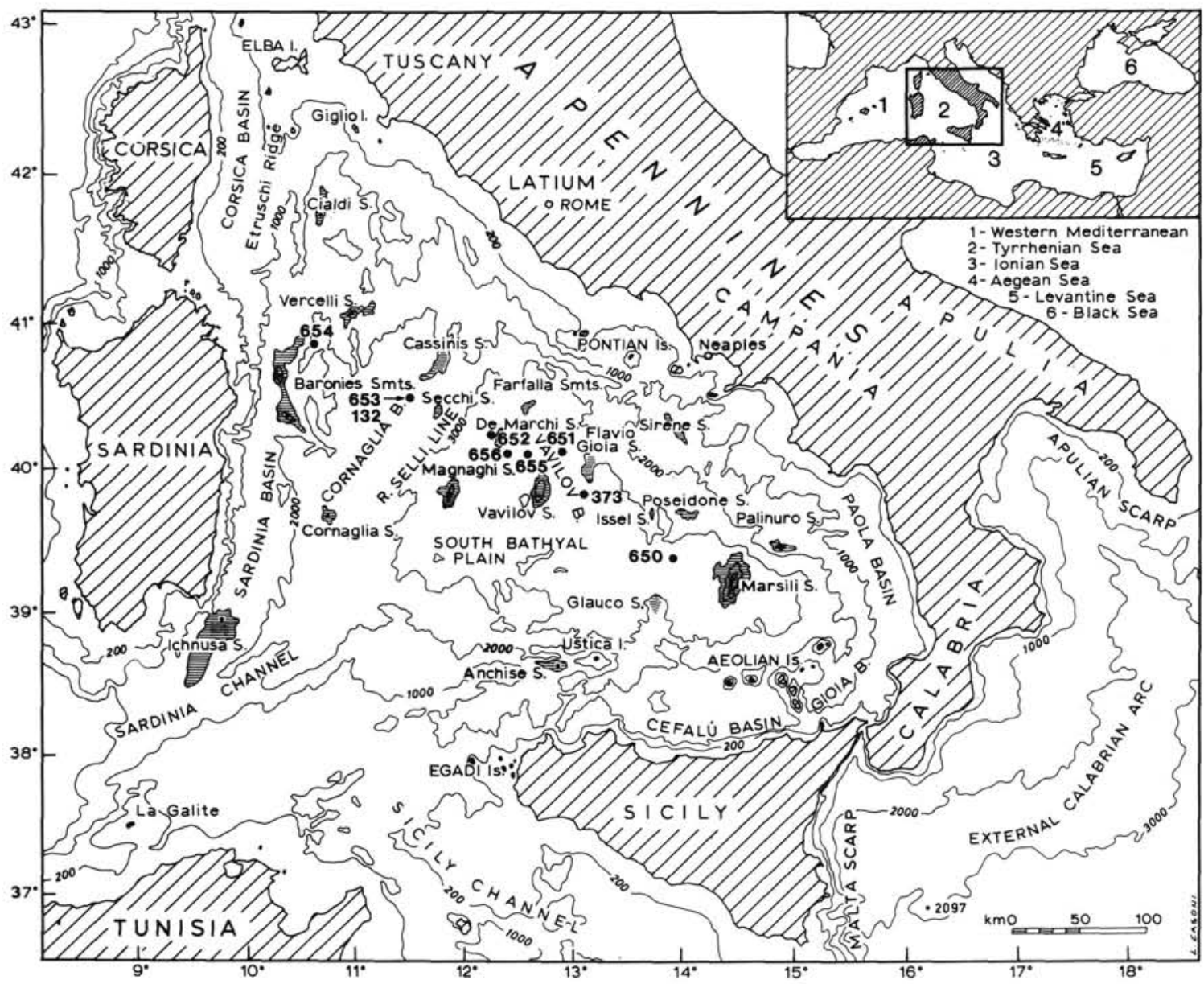

Figure 1. Simplified bathymetric map of the Tyrrhenian Sea, with indication of the main morphostructural features and with location of the DSDP/ODP sites discussed in the text.

ment of oceanic crust. ODP Leg 107 drilling has largely established the evolution of this basin, here described from west to east.

\section{The Western Basin (east Sardinia margin)}

As substantiated by seismic profiles (Fabbri et al., 1981; Moussat, 1983; Rehault et al., 1985; Mascle and Rehault, this volume), the western portion of the south Tyrrhenian Sea is a passive-type margin produced during discrete rifting phases. Most extensional listric faults are north to $\mathrm{N} 30^{\circ} \mathrm{E}$-trending and induce seaward block tilting; however, some blocks are landward tilted. From west to east (from the coast of Sardinia to the Vavilov Basin and to the southern bathyal plain), we find the following major features (Fig. 1):

1. The Sardinia Basin, bordered by the Baronie Seamount and associated ridges (upper margin);

2. The Cornaglia Terrace (or western bathyal plain), less than 3,000 $\mathrm{m}$ deep (middle margin);

3. A series of prominent fault scarps (north-northeast to north-trending), called the Central Fault system or R. Selli Lineament and

4. Some rows of small-amplitude tilted blocks developing down to the De Marchi Seamount (lower margin).

Along this transect, crustal thickness decreases considerably from some 25 to less than $10 \mathrm{~km}$; an impressive shallowing of the Moho is particularly observed across the R. Selli Lineament (Steinmetz et al., 1983; Recq et al., 1984).

\section{The Sardinia Basin}

No drilling data are available yet in this sector, but seismic evidence (Rehault et al., 1985) supports that at least parts of the area experienced subsidence from lower Miocene until middle Pliocene, as also recorded in some sectors of the Sardinia island (Barberi and Cherchi, 1981).

The Miocene subsidence events can tentatively be correlated to those occurring within the Corsica basin to the north (see above), and can be related to postorogenic basin evolution behind and above the main Burdigalian apenninic chain. Such post-tectonic development seems to be supported by the middleupper Burdigalian and upper Tortonian start-ups of the discrete sedimentary cycles occurring in the Corsica basin (Sartori et al., 1987b). This would indicate that sedimentary cycles developed just after the end of the intra-Burdigalian and Tortonian tectonic climaxes (see below). In these terms, the Corsica and Sardinia basins can be regarded as early and limited extensional domains of the Tyrrhenian area (see also Mascle and Rehault, this volume).

\section{The Cornaglia Terrace}

A good stratigraphic control is available to document the stretching phases occurring in the western bathyal plain or Cornaglia Terrace. At ODP Site 654, just a few kilometers east of 
the Baronie Ridge (Fig. 1), rifting started in upper Tortonian, and the area passed from subaerial conditions to water depth of more than 1,000 $\mathrm{m}$ between that time and early Messinian (Kastens, Mascle, et al., 1987). Syn-rift subsidence affected a complex continental basement including metasediments of possible Paleozoic age (Sardinia-type Hercynian basement) and lower Triassic carbonates whose closest correspondents are known in Tuscany (Sartori et al., this volume). The subsidence appears contemporaneous with the previously described onset of magmatism in the north Tyrrhenian basin. Rifting stops (or slows down considerably) during Messinian at ODP Site 654 (Kastens, Mascle, et al., 1987). This indicates that a pre-Messinian oceanic crust can hardly be present in the Tyrrhenian Sea, provided that it was normally emplaced after rifting along the passive margin.

Sites DSDP 132 (Ryan, Hsü, et al., 1973) and ODP 653, drilled toward the center of the Cornaglia Terrace, were terminated just below the Miocene-Pliocene boundary. Both holes confirm the presence, suggested by seismic profiles, of thick evaporitic deposits in a Messinian deep basin, bounded eastward by a coeval structural high located close to the R. Selli Lineament (Fabbri and Curzi, 1979).

\section{The Margin East of the R. Selli Lineament (lower Sardinia margin)}

ODP Site 652 was drilled in a half-graben above a tilted block and recovered Plio-Pleistocene nannofossil oozes underlain by a thick and monotonous Messinian sequence (Borsetti et al., this volume). The latter is mostly made up of fine-grained turbidites, with organic-rich intervals, several thin anhydrite horizons, and one interval of conglomerate (Kastens, Mascle, et al., 1987). The pre-Pliocene sequence recalls in part deposits of the Laga Basin or of the Tuscany grabens in peninsular Italy (Borsetti et al., this volume).

At ODP Site 652 the syn-rift interval includes almost the whole portion of drilled Messinian and also part of lower Pliocene (Kastens, Mascle, et al., 1987; Mascle and Rehault, this volume), maybe up to include the $G$. margaritae Zone. Rifting thus appears younger here than in the Cornaglia Terrace (ODP Site 654). As regards the onset of tectonic subsidence, we only know that almost the whole drilled pre-Pliocene sequence is syn-rift and that it paleomagnetically seems to belong to a single reverse chron of the Gilbert epoch (Channell et al., this volume). In addition to a very high sedimentation and subsidence rate, these data point to the possibility that rifting began at ODP Site 652 only in intra-Messinian times, that is, after the cessation of rifting in the Cornaglia Terrace.

As reported above, the pre-Pliocene sequence is fine-grained throughout, except for a conglomerate interval, some $15 \mathrm{~m}$ thick, whose clasts derive from Southern apenninic/Calabrian/ Sicilian-type rocks of Cretaceous to Tertiary age (Sartori et al., this volume), equivalent to lithologies of the tectonic cover units making up the perityrrhenian Neogene chains. This observation suggests that during (upper?) Messinian the area east of the R. Selli Lineament was a segment of chain being dissected into highs and lows. This paleogeography is typical of a rifting stage, during which the elevated portions of rotating hanging walls could have produced large clasts to the rapidly subsiding and adjacent half-grabens. Many of these highs, presently deeper than $3,000 \mathrm{~m}$ water depth, were also subaerially exposed. In fact, Messinian subaerial breccias have been reported by Dal Piaz et al. (1983) from dredge samples at some 3,000 m water depth on the Flavio Gioia Seamount, that faces the Vavilov Basin to the east (Fig. 1). Extensive occurrence of breccias has also been reported during submersible observations on several nonvolcanic seamounts of the same area (Gennesseaux et al., 1986).

ODP Site 656 is the easternmost site on the east Sardinia margin, close to the De Marchi Seamount which is the last tilted block facing the Vavilov basin (Fig. 1). The base of both Holes 656A and B (Kastens, Mascle, et al., 1987) shows red continental paraconglomerates of probable Messinian age, with clasts deriving from both a Tethyan-type ophiolite nappe and from Tertiary detrital rocks (Sartori et al., this volume). This again indicates that during Messinian the De Marchi Seamount represented a fragment of subaerial chain similar to the ones presently encircling the basin. The site is presently more than 3,200 $\mathrm{m}$ deep, and the Pliocene sequences are condensed, with hiatuses in lower Pliocene and lower Pleistocene (Hole 656A) and complex slumps again in lower Pleistocene (Hole 656B) (Kastens, Mascle, et al., 1987). Here again syn-rift subsidence seems to span from Messinian to lower Pliocene, but syn-sedimentary disturbances reappear in lower Pleistocene.

\section{Subsidence History Across the Western Tyrrhenian Basin (Figs. 2-4)}

Subsidence Related to Rifting. Leaving out the Sardinia Basin, that has probably evolved in a different way, two major intervals of syn-rift subsidence are recorded west and east of the R. Selli Lineament, that is, along the middle and lower Sardinia margin respectively.

Across the Cornaglia Terrace the tectonic subsidence is upper Tortonian to intra-Messinian in age (ODP Sites 654, 653, 132), while east of the R. Selli Lineament, it is Messinian (upper?) to lower Pliocene (up to include the $G$. margaritae Zone?) (ODP Sites 652, 656). During Messinian, then, the R. Selli Lineament apparently separated a deep basin to the west (the Cornaglia Terrace) from an area dissected in lows and highs (some of which subaerial) to the east (lower Sardinia margin).

Post Rift Subsidence. All ODP sites containing a continuous Pliocene sequence $(654,653,652)$ indicate a sudden change in benthic foraminiferal faunas, from epibathyal to deep bathyal, starting from some $2.7 \mathrm{Ma}$ (during the $G$. crassaformis Zone of middle Pliocene; Sartori, Sprovieri, Rio, et al., 1986). Such changes seem slightly diachronous across the east Sardinia margin, becoming younger (from 2.7 to $2.4 \mathrm{Ma}$ ) from east to west (from Site 652 to 653 to 654 ; Sprovieri, pers. comm.). Rather than due to a paleoceanographic event documented by isotope analyses at about 2.4 Ma (Thunell and Williams, 1983), these changes may indicate a rapid and progressive drowning (more than $1,000 \mathrm{~m}$ ) by flexing of the whole Sardinia margin. Depthchange faunal effects are recorded earlier close to oceanic Vavilov basin, and later toward Sardinia. These effects seem to be associated, in space and time, to widespread alkaline olivinic magmatism both in Sardinia, where a peak of activity is recorded between 3 and $2 \mathrm{Ma}$ ago (Beccaluva et al., 1985a) and across a number of submarine volcanoes occupying the area from the island to the Vavilov volcano (see below). Such middle Pliocene strong subsidence may be in part the cause of the middle Pliocene foundering of the Tyrrhenian basin postulated by Selli and Fabbri (1971).

Pleistocene subsidence. A renewal of subsidence is indicated in Pleistocene at ODP Site 656 (upper hiatus in Hole 656A, slumps in Hole 656B) (Kastens, Mascle, et al., 1987). The site is located in the lower Sardinia margin, east of the R. Selli Lineament; this indicates that the line, probably an old structural feature separating domains with different basement (Sartori, 1986), acted as weakness path rejuvenated during Neogene and also during Quaternary (Sartori et al., 1987a).

\section{Evolution of the Western Basin South of $40^{\circ} \mathrm{N}$}

The previous evolution applies for the area enclosed between roughly the $41^{\circ} \mathrm{N}$ lineament and $40^{\circ} \mathrm{N}$. South of this area, no drilling data are available, but the margin development seems more regular from the Sardinia island, across the Cornaglia Terrace, down to the southern bathyal plain. Moreover, the R. Selli 
TECTONIC ACTIVITY

TYRRHENIAN

BASIN

UPPER/MIDDLE SARDINIAN

MARGIN AND S. BATHYAL PLAIN

N 9O/100 E direction of extension

\section{STRATIGRAPHY}

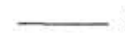

ifting

drifting

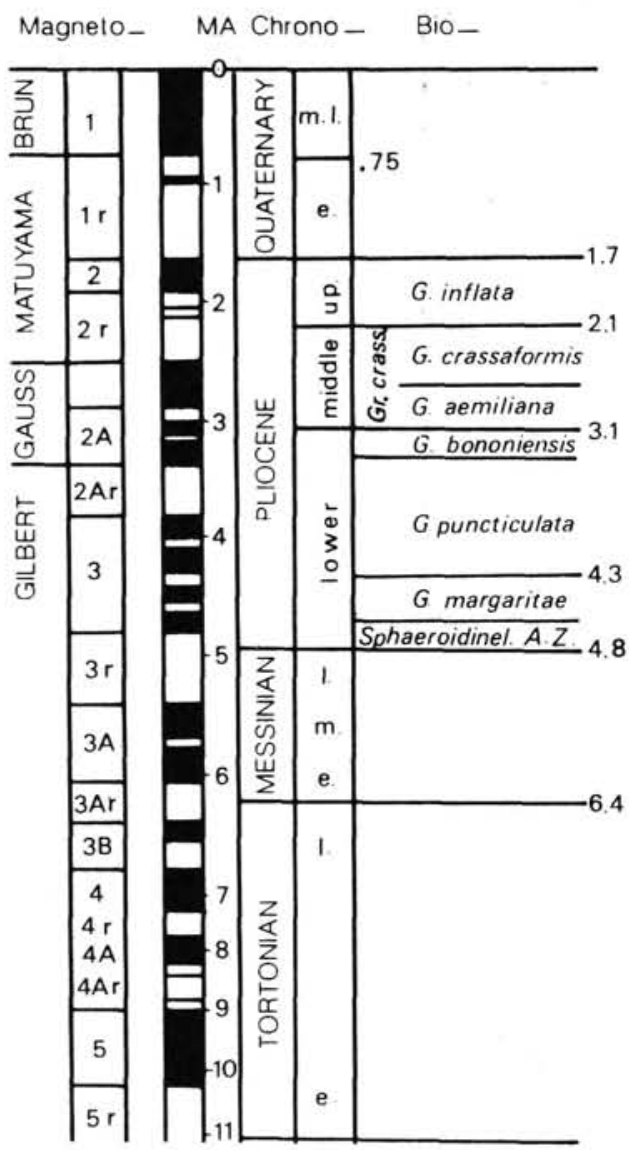

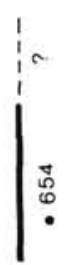

tectonic events

(unconformities,

niatuses.etc.)

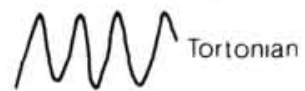

Figure 2. Stratigraphic reference frame for Mediterranean upper Neogene and Quaternary (modified after Channell, et al., this volume), with indication of the time span of main "events" recorded in the southern Tyrrhenian Basin (supported by pertinent DSDP/ODP site results). The column on the right reports the time span of main hiatuses/unconformities recorded in the sedimentary fillings of the peripheral orogens. This figure reports the early stages of evolution of the basin as recorded in the Cornaglia Terrace and in the southern bathyal plain (upper Tortonian to intra-Messinian).

Lineament does not constitute a marked bathymetric feature anymore, and the Messinian evaporite formations seem present on both limbs of the lineament, that is, the Cornaglia Terrace and southern bathyal plain (Fabbri and Curzi, 1979; Moussat, 1983).

An east-trending break across the Sardinia margin at about $40^{\circ} \mathrm{N}$ (transform lineament) might be indicated by magnetic anomalies (Bolis et al., 1981) and by seismic refraction experiments (indicating a shallowing of dense, high velocity bodies at that latitude; Duschenes et al., 1986).
The Central Basin (Vavilov Basin, central volcanoes, and southern bathyal plain)

\section{The Vavilov Basin (Fig. 1)}

The triangular Vavilov Basin, more than $3,400 \mathrm{~m}$ deep, is bounded toward the south at about $40^{\circ} \mathrm{N}$ by two major volcanoes, the Vavilov and the Magnaghi. The basin also contains some linear basement ridges, either buried or standing above the sediment cover (e.g., the Gortani Ridge in correspondence to ODP Site 655) (Fig.1). 


\section{R. SARTORI}

At ODP Sites 651 and 655 (Kastens, Mascle, et al., 1987), as well as at DSDP Site 373 (Shipboard Scientific Party, 1978), tholeiitic basalt units were encountered beneath a cover of Pliocene and Pleistocene deposits (Mascle and Rehault, this volume) indicating that the area is floored by oceanic-type crust, as also suggested by geophysical evidences. Mantle-derived ultramafic rocks were also drilled at bottom of Hole 651 .

\section{The Oceanic Crust}

The age of emplacement of oceanic crust is obviously critical for assessing the evolution of the Vavilov basin as well as of the whole Tyrrhenian Sea. Radiometric, biostratigraphic, and magnetostratigraphic data are discussed in detail.
The MOR-type basalts drilled at DSDP Site 373, on a buried ridge close to the southeastern boundary of the Vavilov Basin, were given an oldest age of $7.3 \pm 1.3 \mathrm{Ma}$ (about uppermost Tortonian) by radiometric K/Ar datings (Barberi et al., 1978). The oldest sediments lying on the basalt flows have been biostratigraphically dated at lower Pliocene (G. puncticulata Zone, at about 3.5 Ma; Shipboard Scientific Party, 1978). A critical review of the available radiometric data indicates that the most reliable age for the basalts is about $4.1 \mathrm{Ma}$ (with the possibility of some lavas being as old as $6.4 \mathrm{Ma}$; Sartori et al., 1987a). The recalculated age corresponds again to the lower Pliocene $(G$. puncticulata Zone, Figs. 2-4), and is in good agreement with the age indicated by fossils in the overlying sediments. Assum-

\section{TECTONIC ACTIVITY}

TYRRHENIAN

BASIN

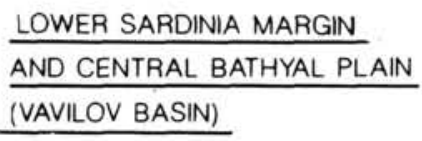

N 90/100 E direction of extension

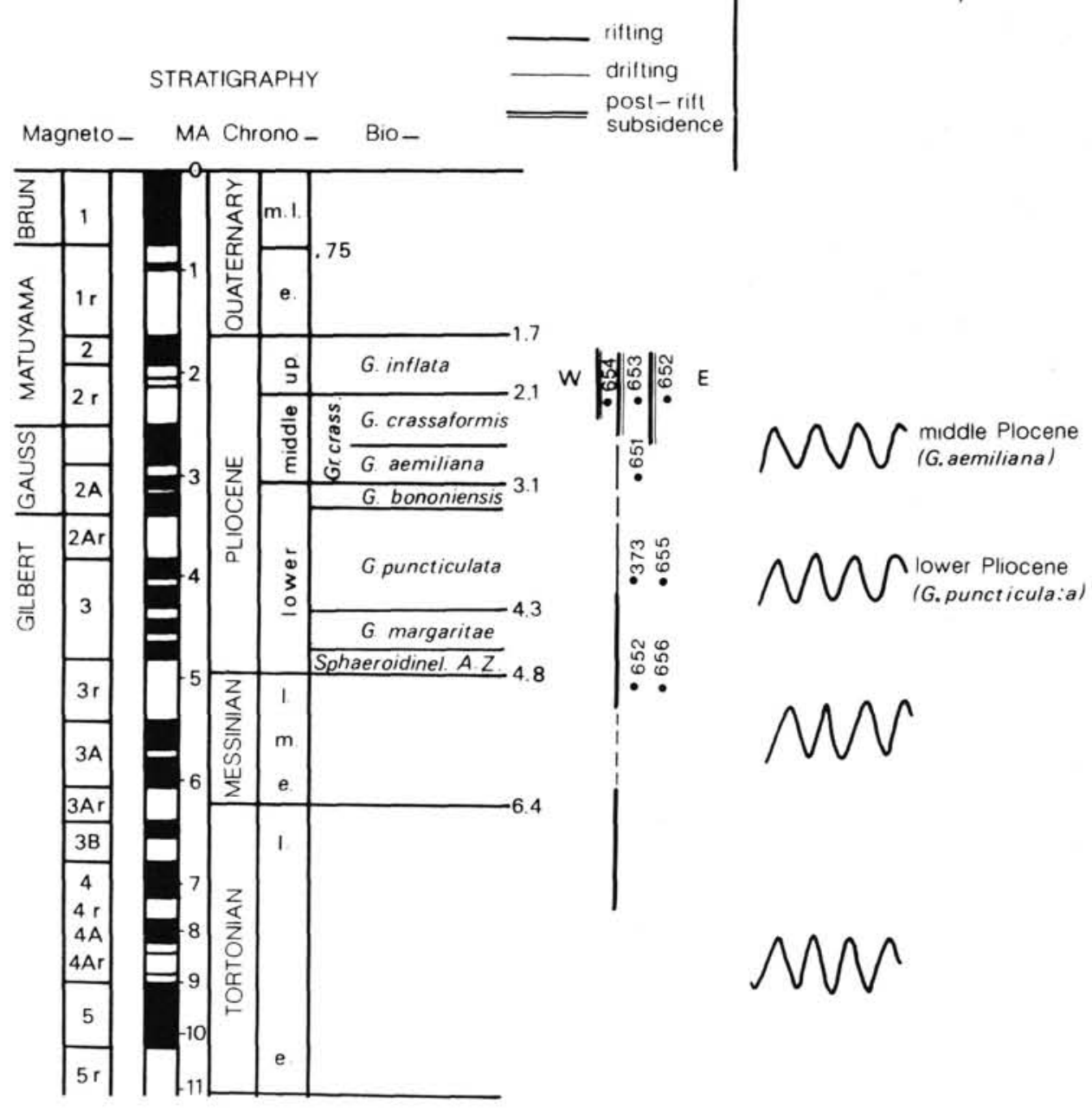

tectonic events

(unconformities

hiatuses etc)

Figure 3. Upper Messinian to middle Pliocene evolution in the central Tyrrhenian Sea and Vavilov Basin compared to events of the perityrrhenian orogens. Explanation as for Figure 2. 
ing that the Vavilov Basin opened in a symmetrical way, this age would also represent the oldest age of the oceanic crust, since Site 373 was located quite close to the base of the apenninic continental margin (a few kilometers west of the Flavio Gioia Seamount, constituted by nappe units of continental crust, Dal Piaz et al., 1983). Symmetric to DSDP Site 373, ODP Site 655 (on the Gortani Ridge) lies close to the last tilted block of the Sardinia margin (the De Marchi Seamount) (Fig. 1). Here again pillow flows of oceanic tholeiitic basalt were drilled (Bertrand et al., this volume; Beccaluva et al., this volume) with ages around $3.5 \mathrm{Ma}$ on biostratigraphic and magnetostratigraphic evidence (Kastens, Mascle, et al., 1987), and of $4.3 \mathrm{Ma}$ following radiometric data (Ferraud, this volume). Both figures again indicate the lower Pliocene G. puncticulata Zone. Such data suggest that in the Vavilov Basin, oceanic crust emplacement began just after the end of the stretching occurring east of the R. Selli Lineament (at ODP Site 652 the syn-rift sequence includes only part of lower Pliocene, maybe up to the G. margaritae Zone, Fig. 3).

ODP Site 651 was drilled near the axis of the Vavilov Basin, in a position where the oceanic crust should be the youngest. At this site, the igneous basement succession is quite complex, including two basalt flow/breccia units separated by dolomitic sediments, rudites containing ultramafic and metamorphic clasts, metadolerites, etc. All these units rest on foliated ultramafics drilled to bottom of hole (Kastens, Mascle, et al., 1987).

The occurrence of rare $G$. crassaformis of middle Pliocene age (time span 3-2.2 Ma, Fig. 3) inside sediments within the two basaltic flows, associated with ultramafic clasts, suggests that the ultramafic body was emplaced as a structural high prior to 3-2.2 Ma. It also suggests that the basaltic units should have an age confined between $3 \mathrm{Ma}$ (first occurrence of $G$. crassaformis) and some $2.2 \mathrm{Ma}$, age of the $G$. inflata Zone of upper Pliocene (Fig. 3), which is present in the oldest datable sediments above the basalts. Such biostratigraphic data agree well with radiometric datings of the flows, indicating an age of $2.6 \mathrm{Ma}$ (Ferraud, this volume). This suggests that basalt emplacement in the central Vavilov Basin occurred during the lower part of $G$. crassaformis Zone of middle Pliocene (i.e., corresponding to the $G$. aemiliana Subzone of the apenninic stratigraphy, Fig. 3), and that oceanic crust accretion in the Vavilov Basin and the ultramafics emplacement at ODP Site 651 were accomplished prior to upper Pliocene. In ODP Site 651 about $40 \mathrm{~m}$ of altered undatable sediments cover the topmost basalt units, and are directly covered by upper Pliocene sediments of the $G$. inflata Zone (Kastens, Mascle, et al., 1987).

As previously indicated (western Tyrrhenian basin), the age of basalts at ODP Site 651 is coeval with the onset of accelerated subsidence and possible flexing across the Sardinia margin (ODP Sites 654, 653, 652).

\section{The Magnaghi and Vavilov Volcanoes (Fig. 1) and the Pliocene Volcanism}

Both the large volcanic edifices are $\mathrm{N} 10^{\circ}-15^{\circ} \mathrm{E}$-trending. The Magnaghi volcano lies near the prolongation of the R. Selli Lineament; the Vavilov volcano lies on the southern extension of the homonymous basin axis.

Seismic data (Selli, 1974) assigned the Magnaghi Volcano an intra-Pliocene age, eventually confirmed by radiometric datings at 3.0-2.7 Ma (Selli et al., 1977), which again means inside the lower part of middle Pliocene.

The Vavilov Volcano is a big and complex edifice whose global reversed magnetic signature may suggest that it was emplaced during the Matuyama chron (Filin et al., in press), i.e., less than $2.4 \mathrm{Ma}$. The topmost and more surficial lava flows are, however, normally magnetized (Filin et al., in press) and have been attributed to an upper Pleistocene rejuvenation of the feeding fissures with emission of alkaline lavas (Gennesseaux et al., 1986; Bertrand et al., this volume).

Ages of both large volcanoes fall again into the middle Pliocene peak of volcanism observed in Sardinia and are coeval with the inferred flexing of the margin. We may argue that eruptions along fissures on the continental margin can account for the setting of the Magnaghi Volcano. However, the Vavilov Seamount, located inside the domain with oceanic crust of the homonymous basin, may have been produced by fissural eruptions postdating the emplacement of oceanic crust, when the domain had already acquired some rigidity by cooling. This again suggests that the oceanic crust was already emplaced by middle Pliocene. Fissures feeding the Vavilov Volcano have been rejuvenated in Pleistocene, when also a tilting of the whole edifice occurred (Gennesseaux et al., 1986).

By connecting Sardinia and central Tyrrhenian volcanoes, and taking into account the volcanic edifices detected on the margin (Sartori, 1986), we observe a set of Pliocene volcanic bodies occupying a belt oriented east-west in which edifices erupting alkali-olivinic-tholeiitic lavas appear elongated roughly along north-trending fractures. Most extensional listric faults also strike roughly north. This may be consistent with a regional extensional stress trending east to $\mathrm{N} 100^{\circ} \mathrm{E}$ (Sartori, 1986, see also the "transform faults" of Selli, 1981). A modest Pliocene volcanic arc seems to encircle this extensional area just east of the Vavilov basin, connecting Ponza Island (Savelli, 1984), Albatross Seamount (Sartori, 1986), Glauco Seamount, and Anchise and Aceste Seamounts (located north of Sicily) (Calanchi et al., 1984; Beccaluva et al., 1985b).

\section{Evolution of the Southern Bathyal Plain}

South of $40^{\circ} \mathrm{N}$, the seismic characters of the central Tyrrhenian are different from those of the Vavilov basin. Although the bathyal plain lies at the same depth and displays comparable geophysical characters as in the Vavilov Basin, here the seafloor is very flat, showing only subdued basement features buried and smoothed by sediments. The sedimentary cover contains Messinian evaporites (Fabbri and Curzi, 1979; Moussat, 1983) locally, beneath a Pliocene-Quaternary sequence of almost constant thickness. This is a major difference compared to the northlying Vavilov Basin, where the oceanic crust is covered directly by Pliocene layers, sometimes with a quite thick sequence of Pliocene-Pleistocene sediments (Moussat et al., 1986). Coupled with the differences in the evolution of the east Sardinia margin south of $40^{\circ} \mathrm{N}$, these observations may suggest that oceanic crust, if present in the area, could have started forming earlier, in intra-Messinian times.

This area may have been then the locus of an initial oceanic accretion, propagating northward of a transform lineament $\left(40^{\circ} \mathrm{N}\right)$ in lower Pliocene time, and would have resulted in the triangular configuration of the central Tyrrhenian bathyal plain (Fig. 5; see also Moussat et al., 1986). The occurrence of an oceanic crust of Messinian age may be consistent with the first stop of stretching recorded in the upper Sardinia margin (ODP Site 654, see above). A north-south difference in timing of the stretching is also observed along the Calabrian margin, conjugate of the Sardinia one. In fact, north and south of the Catanzaro isthmus two perityrrhenian basins are present (Paola and Gioia).

In the southern one (Gioia basin) stretching and strong subsidence occurred from upper Tortonian to Messinian (Fabbri et al., 1980); in the northern one (Paola basin) there are arguments in favor of a lower Pliocene rifting event (Barone et al., 1982) with further phases in upper Pliocene-Pleistocene.

In the southern bathyal plain, extensional stresses should be more or less the same as in the north-lying Vavilov Basin (east to $\mathrm{N} 100^{\circ} \mathrm{E}$ ); this would imply similarly oriented transform linea- 
ments separating the southern bathyal plain from the north Sicilian margin (Boccaletti et al., 1986b). The activity of these transforms should span at least from upper Tortonian to middle Pliocene (from some 9 to $2.5 \mathrm{Ma}$ ).

The north Sicilian margin is affected by a system of faults of various directions. In the Cefalù basin, a transpressional tectonism affecting Messinian evaporites and earlier intervals has been suspected (Barone et al., 1982; Trincardi and Zitellini, 1986).

\section{The Southeastern Tyrrhenian Sea (Marsili Basin)}

\section{The Marsili Basin}

Whereas the Vavilov Basin displays a roughly triangular shape, the Marsili basin is rhombohedral (Figs. 1 and 5). However, both areas share the same water depth and crustal thickness (less than $10 \mathrm{~km}$ ), although they are disconnected by a subdued sill characterized by a thicker crust (some $15 \mathrm{~km}$, Steinmetz et al., 1983). One hole (ODP 650) was drilled in the basin, near its western limit and as far away as possible from the products of the Marsili Volcano, with the purpose of drilling the oldest domains of the basin possibly floored by oceanic crust (Kastens, Mascle, et al., 1987).

Basalt flows were encountered beneath a thick (about $600 \mathrm{~m}$ ) pile of mostly volcanogenic turbidites. The rocks are, however, different from those of the Vavilov Basin, because they are highly vesicular and display petrochemical affinities that recall calcalkaline suites (Beccaluva et al., this volume). No radiometric age has been obtained, but the sediments just overlying the basalts are of uppermost Pliocene age, about 1.8 Ma (Kastens, Mascle, et al, 1987).

Although these indications are still controversial, mainly as regards the significance of rock chemistry and the modest basalt penetration of the site $(35 \mathrm{~m})$, we may assume that the crust flooring the Marsili Basin is significantly younger than the one drilled in the central Tyrrhenian, and probably younger than the younger products (middle Pliocene) of that same area. The Marsili Basin is likely the most recent portion of the Tyrrhenian Sea, and essentially post-middle Pliocene in age.

\section{Stretching and Subsidence History in and Around the Marsili} Basin (Fig. 4)

Unfortunately no drilling data are available to understand the rifting phase of these regions; some indications are given by seismic profiles. Along the sill separating the Marsili Basin from the central Tyrrhenian Sea, listric faults seem to affect and tilt reflectors of the Plio-Pleistocene sequence (Mascle and Rehault, this volume). On the opposite side, within the Paola basin, synrift geometrical wedging is also observed in reflectors tentatively attributed to upper Pliocene-lower Pleistocene times (Barone et al., 1982).

Concerning the amount of subsidence of the Marsili basin, we should consider that the lavas of Site 650 were drilled at a depth of some $4,100 \mathrm{~m} \mathrm{(3,500}$ of water and 600 of sediments). Such a depth is not consistent with the marked vesicularity (up to $20 \%-30 \%$ ) of the lavas. The most conservative estimates can not place eruptions at a water depth greater than 2,000-2,500 m (Kastens et al., 1988). This would imply a very strong post-lower Pleistocene subsidence rate for the Marsili basin, in the order of $1 \mathrm{~mm} /$ year, faster than that expected by simple thermal contraction. Such a marked deepening is paralleled by the huge deposition of volcaniclastic products. Actually, a comparable strong Pleistocene subsidence is recorded at ODP Site 651 (great increase in accumulation rates), and at ODP Site 656 (hiatus in Hole 656A, slumps in Hole 656B). These sites are located east of the R. Selli Lineament, that has likely played a role also in Pleistocene times, separating regions with different subsidence history. It is interesting to note that the internal margins of Southern Apennines, in addition to those of Calabria, have also experienced strong subsidence, mostly during Pleistocene. In these areas the subsidence rates (Ortolani and Aprile, 1977; Ciaranfi et al., 1983) are almost identical to those observed at ODP Site 650 , suggesting that the strong subsidence recorded in the Marsili Basin is not only due to the load effect of the huge Marsili volcano.

\section{The Marsili Volcano and the Pleistocene volcanism}

The Marsili Volcano, with 3,000 m relief, is made of complex accumulations of products of different petrochemical affinity: tholeiitic near the base and calc-alkaline toward the top (Selli et al., 1977). Only the products from the top have been radiometrically dated; they are less than 0.2 Ma old (Savelli, 1984). Magnetic anomalies across the volcano (which is elongated in a $\mathrm{N} 20^{\circ} \mathrm{E}$ direction) show a symmetry comparable to anomalies at oceanic spreading centers, but this observation can be also explained by the different chemistry moving from bottom to top (Selli, 1970).

More or less coeval to the Marsili activity, other alkaline volcanic edifices are observed (Etna, Ustica Island, volcanic islands of the Sicily Channel, reactivation of Vavilov fractures, alkali-olivinic basalts at ODP Site 654 , dikes at Baronie Seamount, basalts close to the Vercelli Seamount, Logudoro volcanism in Sardinia; Sartori, 1986). In general, such extensional products affect the entire Tyrrhenian region, and sketch a belt roughly oriented $\mathrm{N} 110^{\circ}-130^{\circ} \mathrm{E}$, that is significantly rotated to northwest-southeast when compared with the Pliocene one (Sartori, 1986; Sartori et al., 1987a). This would imply a similarly oriented local extensional stress during Pleistocene.

The Pleistocene volcanism of the southeast Tyrrhenian Sea appears mostly of calc-alkaline to shoshonitic nature. In addition to the lavas drilled at ODP Site 650 and to the Marsili top, this volcanism is found in the Aeolian Islands, and it also characterizes a row of drowned edifices, including the Palinuro Volcano (Colantoni et al., 1981b), which are roughly arranged in a semiannular arc internal to the Calabrian Arc (Selli et al., 1977). The oldest radiometric dating available for this complex indicates 1.3 Ma (lower Pleistocene) within the Aeolian Islands, and the activity persists today (Savelli, 1984; Beccaluva et al., 1985b). Meanwhile, the so-called Roman and Campanian volcanisms affect the internal margin of the Apennines, from the Tuscan domain toward the Naples area (on the intersection with the $41^{\circ} \mathrm{N}$ lineament); these provinces are characterized by alkaline and high- $\mathrm{K}$ volcanics active from lowermost Pleistocene until present times.

\section{Summary of Main Events in the Tyrrhenian Sea (Figs. 2-4)}

Except from a few evidences of lower Miocene (post-lower Burdigalian?) limited subsidence detected in the Corsica and Sardinia Basins, that does not lead to strong stretching, rifting starts in both the northern and southern Tyrrhenian Sea in upper Tortonian times.

In the north Tyrrhenian (north of a major east-west lineament occurring at $41^{\circ} \mathrm{N}$ ) the rifting migrates eastward and affects peninsular Italy (Tuscany) up to Pleistocene times. No high crustal thinning is produced.

South of $41^{\circ} \mathrm{N}$ (in the south Tyrrhenian basin) a strong extension occurred through some discrete, short-living rifting phases. A first rifting episode, characterized by north-trending extensional listric faults, affected the Cornaglia terrace west of the R. Selli Lineament (Fig. 1). This phase spans from upper Tortonian to intra-Messinian times (ODP Sites 654 and 653 and DSDP Site 132) and leads to the generation of a deep Messinian basin in the Cornaglia Terrace. We may hypothesize that the first rifting slow-down is correlatable with the beginning of oceanic crust emplacement in the southern bathyal plain. 
TECTONIC ACTIVITY

\author{
SOUTH EASTERN BATHYAL \\ PLAIN (MARSILI BASIN)
}

N $110 / 130$ E direction of extension

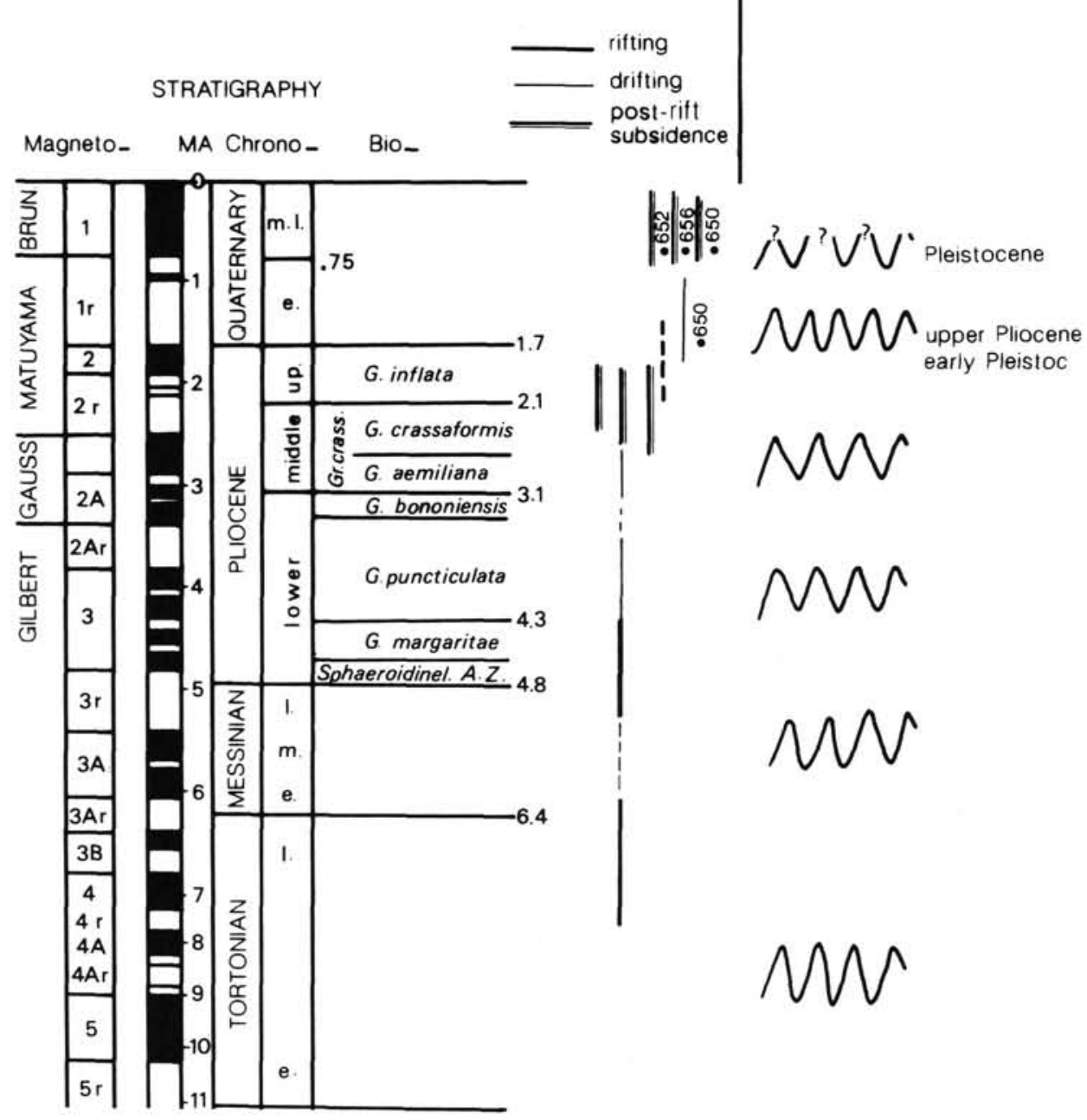

tectonic events (unconformities, hiatuses, etc.)

Figure 4. Upper Pliocene to Recent evolution of the Tyrrhenian Basin, as recorded mainly in its southeastern portion and in the Marsili Basin, compared to events in the perityrrhenian orogens. Explanation as for Figure 2.

East of the R. Selli Lineament and north of $40^{\circ} \mathrm{N}$, stretching extends from (upper?) Messinian to lower Pliocene (up to include the G. margaritae Zone?). Oceanic crust emplacement in the facing Vavilov Basin starts, after the end of the stretching, around 4.3-4.1 Ma (ODP Site 655, DSDP Site 373) (base of the G. puncticulata Zone of lower Pliocene) and goes on up to middle Pliocene, some 2.6 Ma ago (ODP Site 651, i.e., the G. aemiliana Subzone of middle Pliocene, Fig.3). Ultramafic rocks were also emplaced at the accretion axis (ODP Site 651).

These kinematics imply a rift propagation from the southern bathyal plain to the Vavilov basin, possibly with an anticlockwise rotation of the eastern block due to a triangular opening (wider to the south than to the north).

Strong (partly thermal?) subsidence of the oceanic domain also started in middle Pliocene leading to a flexing of the east
Sardinia margin. This evolution was accommodated by extensional faults/fissures oriented north-south along which volcanic edifices were often erupted. The extensional belt occupies an east-trending area that indicates a similar arrangement of extensional stresses at least from upper Tortonian to middle Pliocene. This stress pattern, also confirmed by the north strike of extensional listric faults, implies that in the same time span the north Sicilian margin was mainly subjected to transform/transpressional evolution.

Post-middle Pliocene rifting and oceanic accretion seem only confined to the areas around the Marsili Basin (Figs. 4, 5); extensional stresses again affect the whole Tyrrhenian basin, leading to rejuvenation of older lineaments and volcanic edifices, but they appear rotated $20^{\circ}-30^{\circ}$ clockwise with respect to the pre-middle Pliocene ones (from $\mathrm{N} 90^{\circ}-100^{\circ} \mathrm{E}$ to $110^{\circ}-130^{\circ} \mathrm{E}$ ). 
This stress change over time seems to be paralleled by the change in strike of the slab presently subducting beneath the Tyrrhenian Sea: north in its deeper portion and northeast in the shallower one (Ritsema, 1979).

Calc-alkaline/shoshonitic high-K volcanism became much more important than before (Roman/Campanian provinces, $\mathrm{Ae}$ olian Islands area). Huge amounts of volcaniclastic materials were then discharged in the rapidly subsiding portions of the ba$\sin$ (accumulation rates up to $60 \mathrm{~cm} / \mathrm{k}$.y.). The Pleistocene subsidence appears to be very strong in the Marsili Basin (ODP Site 650 ) but it also affects the whole Tyrrhenian domain located east of the R. Selli Lineament, as evidenced in ODP Sites 651 and 656.

The Pleistocene stress pattern implies transform lineaments more or less parallel to the present strike of Southern Apennines and normal to the Calabria-Peloritan arc (Gasparini et al., 1982).

\section{OUTLINE OF THE PERITYRRHENIAN NEOGENE CHAINS IN RELATION TO BASIN EVOLUTION}

The apenninic, Calabrian, and Maghrebian orogenic systems developed, with an African-Adriatic vergence, mostly in Neogene times, along the eastern and southern margin of the present

\section{TENTATIVE KINEMATIC SKETCH OF THE ITALIAN AREA}
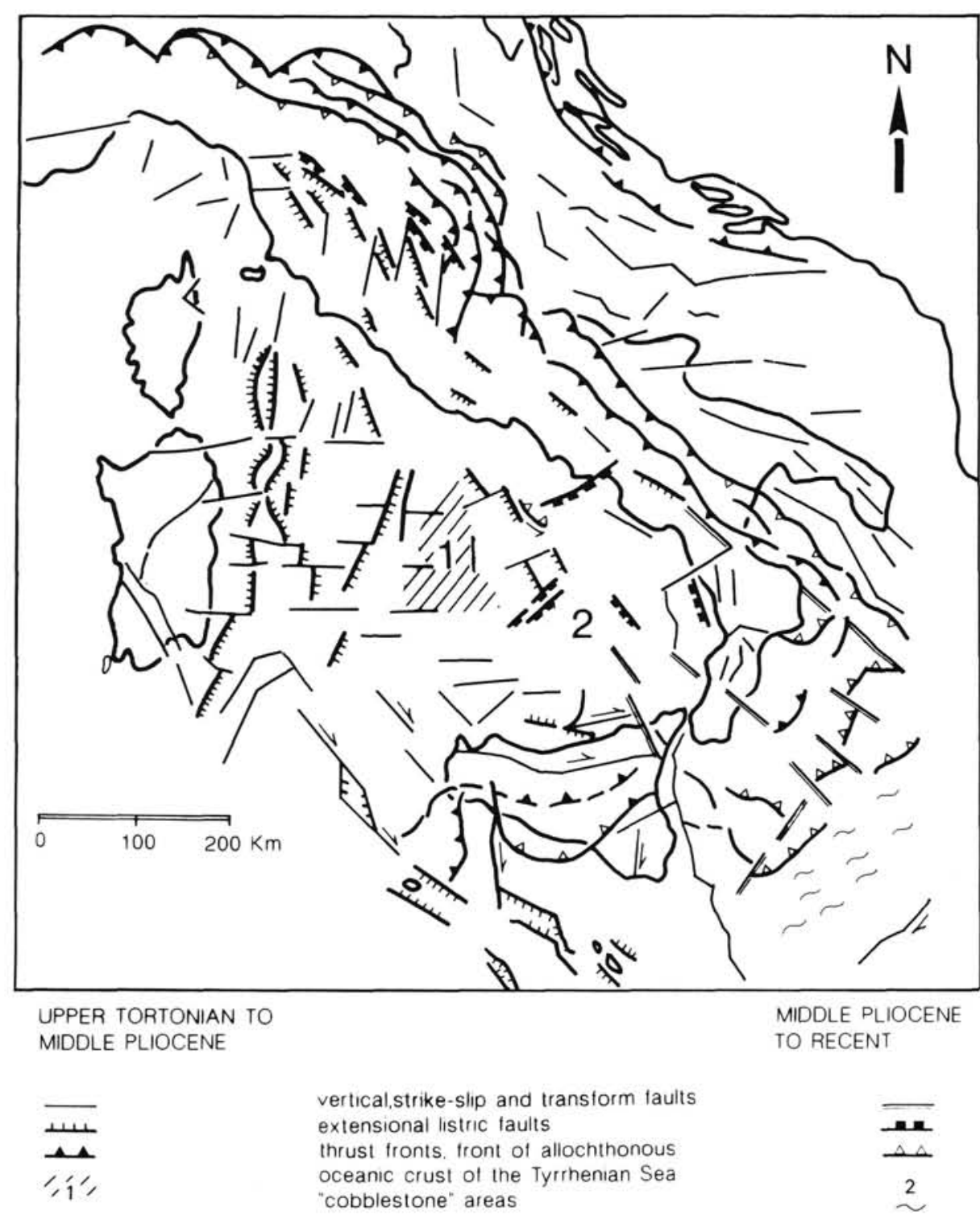

Figure 5. Tentative sketch of the main post-upper Tortonian tectonic elements in the Tyrrhenian Basin and in Apennines-Calabria-Sicily (land areas modified and simplified after Patacca and Scandone, 1987). Structures are separated into two time intervals, corresponding to upper Tortonian-middle Pliocene and to middle Pliocene-Recent, respectively. Note the triangular shape of the oceanic crust in the central Tyrrhenian Sea (Messinian?-middle Pliocene) and the rhombohedral shape of the post-middle Pliocene oceanic crust in the Marsili Basin. Note also the $41^{\circ} \mathrm{N}$ lineament separating the northern and southern Tyrrhenian Sea and how its eastern extension reaches the region of Central Apennines. For further explanations see text. 
Tyrrhenian Sea (see Sartori, et al., 1987b, and references therein). No compressional tectonism occurred in the same time on the opposite side of the basin (Corsica and Sardinia). Presently, the orogens form two major arcuate features, the Northern Apennines arc and the Southern Apennines-Calabria-Sicily arc ( $\mathrm{Pa}$ tacca and Scandone, 1987). These arcs merge in the Central Apennines, a structurally complex area (Locardi, 1986) where two major transverse lineaments are observed: the Ancona-Anzio Line (Castellarin et al., 1978) and the Ortona-Roccamorfina Line (Locardi, 1986; Patacca and Scandone, 1987).

In spite of pre-Neogene "Ligurian phases" (e.g., Giglia, 1974; Elter, 1980; Boccaletti et al., 1980) and of true Alpine phases with an European vergence (Scandone, 1982), the chains encircling the eastern border of the Tyrrhenian Basin were affected by a first, strong phase with an African vergence culminating during Burdigalian times (e.g., D'Argenio et al., 1975; Parotto and Praturlon, 1975; Catalano and D'Argenio, 1982). It is commonly agreed that the drifting of the Corsica-Sardinia block, and the oceanic accretion of the Western Mediterranean Basin, ended in intra-Burdigalian times, after a rifting phase initiated in middle/upper Oligocene (Edel, 1980; Rehault, 1981; Cherchi and Montadert, 1982). This major dynamic event is clearly correlatable to the first strong Adria-verging deformations of the Apulian margin and produced a metamorphic belt (greenschist facies) known from the Northern Apennines (Apuane Alps) to Calabria (San Donato Unit) (Carmignani et al., 1978; Scandone, 1982). Subduction/collision processes were accompanied by a north- to northwest-dipping Benioff plane beneath Sardinia, by eruptions of calc-alkaline lavas (Savelli, 1984), and by graben/half-graben formations in that island (Cherchi and Montadert, 1982). The emplacement of the deep crustal units of the Calabride nappes above the Adria margin in the Calabrian Arc also occurred at this time (Scandone, 1982). Within the Tyrrhenian Sea, the Burdigalian phase was followed by the development of the so-called "postorogenic" Corsica and Sardinia basins. The deformations of the Burdigalian phase should have been rather cylindrical all along the entire orogenic systems.

After middle Miocene tectonic pulses recorded in some segments of the orogens (Langhian, Serravallian, see Boccaletti et al., 1986a), the next strong and generalized compressional phase occurred in Tortonian times. This phase of serrage (Tuscan phase in the Northern Apennines, Boccaletti et al., 1980) terminated at about 13-10 Ma (age of the latest calc-alkaline products in Sardinia and youngest metamorphism in the apenninic greenschist belt). Strong transcurrent motion occurred then along major wrench faults in the perityrrhenian systems that started being dissected. The displacements began in Burdigalian times, affecting the Sangineto (sinistral), and Taormina (dextral) Lines both bounding the crystalline units of the Calabrian Arc (Amodio Morelli et al., 1976). The source areas for these deformations have to be looked for again in the Western Mediterranean Basin. In fact, according to ODP Leg 107 results, major stretching in the Tyrrhenian Sea only occurs since upper Tortonian times (ODP Site 654, see above). Moreover, similarly to Apennines-Calabria-Sicily, compressional tectonism of about Tortonian age is recorded around the Western Mediterranean also in Tunisia (Bouillin et al., 1986), in the Ligurian Sea (Fanucci, 1986), and in the Balearic Islands (Bourrouilh, 1973; Pomar et al., 1983; Curzi et al., 1986).

No major differences seem to be established yet in the Tyrrhenian Sea between the northern and southern portions. The whole basin is occupied by a Tortonian orogenic belt, largely emerged and eroded as indicated by the middle-upper Miocene hiatus in the Corsica Basin and by the deposition of crystalline clastics of internal (western) provenance within the apenninic foredeeps/foretroughs (Carrara and Serva, 1982).
Extensional tectonic activity affected the whole Tyrrhenian Sea apparently just after the Tortonian compressive event. From this moment, the basin became the "tectonic source area" (Sartori and Scandone, 1985) for the peripheral deformations (Fig. 5). Extension started in upper Tortonian (some 9-10 Ma ago), with moderate rifting in the north Tyrrhenian Basin and more severe rifting in the south Tyrrhenian Basin. In the latter area it produced the basins beneath the present-day Cornaglia Terrace (ODP Sites 654, 653). The first rifting episode spans from upper Tortonian to intra-Messinian times (ODP Site 654). This is also a period of continuous subsidence everywhere, inside and around the basin, both in the inner chain portions and in the foredeeps ("Sahelian cycle," see Borsetti et al., this volume). For instance, subsidence in the Laga basin (the foredeep at the southeast limit of Northern Apennines) is demonstrated by the change from slope to deep marine facies and to deposition of turbiditic flysch (Laga Formation) in a deep basin. Coeval "postorogenic" deposits developed on the Sicilian chain (Terravecchia Formation) (Borsetti et al., this volume), in intermontane basins in Calabria (Di Nocera et al., 1979), may be in grabens of the Tyrrhenian side of Tuscany.

In the Northern Apennines, unconformities and evidences of tectonic transport recur only during middle-upper Messinian (Iaccarino and Papani, 1979; Marabini and Vai, 1985; Castellarin and Vai, 1986). In the Central Apennines strong Messinian wrenching accompanied most of the $50-\mathrm{km}$ dextral throw along the Ancona-Anzio Line, as evidenced by the style of sedimentation of the thick Laga turbidites (Castellarin et al., 1978). The Latium-Abruzzi carbonate platform of Central Apennines was in the meantime split into north-verging thrust units. An intraMessinian "phase" is also recorded in the Southern Apennines (Ortolani, 1979) as well as in Calabria (Moussat, 1983). In Sicily, an unconformity splits the Messinian interval into two cycles (Decima and Wezel, 1973).

This intra-Messinian event appears temporally related to the cessation of rifting in the Cornaglia Terrace and to the possible emplacement of oceanic crust in the southern bathyal plain (Fig. 2). Such drifting may have initiated a strong anticlockwise rotation of Southern Apennines (Incoronato and Nardi, 1987) with respect to the Northern Apennines. Due to this differential rotation, the area near the Ancona-Anzio Line, at the boundary between Northern and Central Apennines, became a complex domain with different structural trends (from north-south to east-west, Castellarin et al., 1978; Calamita and Deiana, 1988); an increase in arc formation of the Northern Apennines (Lavecchia et al., 1988) may also have started. With this event, the two previously mentioned perityrrhenian arcuate features were eventually built up and will then follow different evolutions.

The east-trending $41^{\circ} \mathrm{N}$ lineament in the Tyrrhenian Sea, which reaches to the east the region of Central Apennines and possibly represented a transfer/transform fault during the upper Tortonian-Messinian rifting, may have been rejuvenated in the intra-Messinian event, inducing a drowning of the whole sector to the south. This fact is demonstrated on seismic grounds by the occurrence of north-trending Pliocene valleys and canyons eroding sediments in the Corsica basin (Fig. 1) and driving them to the South (Fabbri et al., 1981).

After the intra-Messinian tectonic acme, continuous subsidence is again recorded almost everywhere in the chains and related foredeeps, where no unconformities are observed. These new sedimentary cycles, which include the Miocene-Pliocene boundary and the corresponding dramatic changes in depositional environment, last until toward the base of the G. puncticulata Zone (lower Pliocene). In the Tyrrhenian Basin, this interval corresponds to rifting with subsidence east of the R. Selli Lineament (ODP Sites 652, 656; Fig. 3). 
The next event is observed within the $G$. puncticulata Zone and is very important in the entire orogenic systems, and mainly in the Southern Apennines.

In the Northern Apennines we observe an advancing piggyback thrust system (Pieri and Groppi, 1981; Castellarin and Vai, 1986; Patacca and Scandone, 1987) and large plastic nappes of "argille scagliose" within sediments of the G. puncticulata Zone (e.g., Marecchia Valley). In the foredeeps, subsidence migrated eastward. In the Marche and Abruzzi, for instance, the lower Pliocene main depocenter (Teramo Basin) is shifted several kilometers to the east of the Messinian one (Laga Basin, Casnedi et al., 1982).

During the lower Pliocene event, near the Ancona-Anzio Line the Latium-Abruzzi carbonate platform units were geometrically covered by east-verging thrust units (with throw of some kilometers) of the basinal domain of the Northern Apennines (Castellarin et al., 1978). With this phase, the Ancona-Anzio Line behaved mostly as a lateral ramp for the development of deformations toward the external zones of the northern apenninic arc (Calamita and Deiana, 1988), while strong dextral wrenching was mostly transferred to the Ortona-Roccamonfina Line, that is, to the boundary between Central and Southern Apennines (Locardi, 1986).

In the whole south apenninic segment, the $G$. puncticulata event corresponds to a strong drowning of the carbonate units of the Apulian foreland, often leading to sedimentation of deep water clays and oozes directly above Upper Cretaceous carbonate platform sequences. This sudden drowning is observed up to several tens of kilometers internal to the present front of the chain (Casnedi et al., 1982) and up to only 10-20 km east of the present Tyrrhenian coast, above the so-called internal Apulian platform of Mostardini and Merlini (1986). This may indicate that portions of the south apenninic chain were displaced eastward in a newly created, large foredeep and were in the meantime probably strongly rotated in an anticlockwise sense, as also indicated by the different strikes of pre-Pliocene thrust fronts (Ortolani, 1979). The present chain/foredeep system displays a horse/duplex imbrication style (Patacca and Scandone, 1987) that contrasts markedly with the piggy-back one of the Northern Apennines (Bally et al., 1986; Castellarin and Vai, 1986; Patacca and Scandone, 1987).

The huge Malta and Apulia escarpments bordering the Ionian Sea also appear strongly rejuvenated during the Messinian and mostly the lower Pliocene events (Carbone et al., 1982 for the Malta escarpment). In the Sicily Channel rifting also probably starts in lower Pliocene, because no Messinian evaporites seem to be present in the grabens/pull-apart basins (Winnock, 1981).

As evidenced for the Tyrrhenian Basin (ODP Sites 655 and 651 , DSDP Site 373) the G. puncticulata event may well correlate with end of rifting and beginning of drifting in the Vavilov Basin, as well as with a rift propagation from the southern bathyal plain to the north of the $40^{\circ} \mathrm{N}$ supposed transform lineament (Fig. 3). The resulting processes lead to the triangular shape of the emplaced ocean crust (Fig. 5), and may account for the rotation of south apenninic chain units and for their transport in the lower Pliocene Bradanic-Ionian foredeep, south of the Central Apennines.

As reported previously, during the whole period from upper Tortonian to lower Pliocene, Sicily and the north Sicilian margin should have experienced a general east-west dextral transpression with clockwise rotation of thrust units (Ghisetti and Vezzani, 1982; Barone et al., 1982; Boccaletti et al., 1986b; Incoronato and Nardi, 1987; Trincardi and Zitellini, 1987).

In the perityrrhenian orogens, the next widespread unconformity is recorded, both in the internal chains and in the fore- deeps, in middle Pliocene (Fig. 3), toward the base of the $G$. crassaformis Zone (in the G. aemiliana Subzone of apenninic stratigraphers; Patacca and Scandone, 1987). In the north apenninic foredeeps it corresponds to further piggy-back transport of thrust units; in the internal "postorogenic" basins to the beginning of a new sedimentary cycle. In the Central Apennines it is particularly evidenced by thrusting occurring in the vicinity of the Ortona-Roccamonfina Line (Locardi, 1986), while the Ancona-Anzio Line becomes almost inactive. In the Southern Apennines it often corresponds to a hiatus of the sedimentary sequences in the internal basins, and to thrusting and other deformations in the external and foredeep areas (Casnedi et al., 1982).

In the Tyrrhenian Sea the middle Pliocene event seem to correspond to the end of oceanic crust emplacement in the Vavilov basin and to a progressive flexing/downwarping of the eastern Sardinia margin. It also corresponds with a peak of alkali-olivinic volcanism that occurred in the whole area from the Sardinia Island to the Vavilov volcano.

The pattern of deformation in both the northern and the southern apenninic arcs drastically changes after middle Pliocene times (Figs. 4, 5). At least two more unconformities are recorded in late Pliocene ( $G$. inflata Zone) and inside Pleistocene in the deformed foredeep areas (Patacca and Scandone, 1987).

In the northern apenninic arc, beneath the Po Plain, the previous piggy-back migration of tectonic fronts ceases almost completely, and some late Pliocene to Pleistocene fronts develop 40-50 km internally of the middle Pliocene fronts (Castellarin and Vai, 1986).

In the Southern Apennines, the chain is affected more by northwest-southeast transtensional/transpressional faults than by almost pure northeast-verging thrusts as it was during the previous events (Gasparini et al., 1982; Patacca and Scandone, 1987). The whole sector becomes then a sort of lateral ramp for the pure thrust deformations occurring presently off the Ionian side of the Calabrian Arc (Rossi and Sartori, 1981) at the hinge zone of the southern arcuate orogen (Fig. 5). In Sicily Pleistocene structures seem to develop at high angles with the pre-middle Pliocene thrust fronts and fold axes (Catalano et al., 1988).

Large-scale modifications also characterize the Tyrrhenian Sea in the meantime. The locus of oceanic accretion shifts from the Vavilov to the southeast-lying Marsili Basin (Figs. 4, 5) and the extensional stress revealed by volcanic alignments turns from $\mathrm{N} 90^{\circ}-100^{\circ} \mathrm{E}$ to about $\mathrm{N} 120^{\circ}-130^{\circ} \mathrm{E}$ (Sartori, 1986). Transpressional/transtensional structures develop across the whole south apenninic Tyrrhenian margin (Moussat, 1983; Trincardi and $\mathrm{Zi}$ tellini, 1987). Some volcanic fractures are partially rejuvenated as west as Sardinia (Vavilov, ODP Site 654 ). The major volcanic activity (characterized by high-K alkaline suites) occurs in Pleistocene in peninsular Italy, from Tuscany to Naples, and in the Aeolian Islands and related areaas, where a calc-alkaline/ shoshonitic series erupts back of the hinge zone of the southern arc.

In Pleistocene, once more strong subsidence characterizes the whole area east of the R. Selli Lineament (ODP Sites 652, $656,651,650$ ), with rates in the order of $1 \mathrm{~mm} /$ year comparable to the ones measured in the internal zones of Southern Apennines (Ortolani and Aprile, 1977; Ciaranfi et al., 1983). Meanwhile, in some sectors of the Calabrian Arc, uplifts of more than $1 \mathrm{~mm}$ /year are recorded since lower Pleistocene (Ghisetti and Vezzani, 1982 and references therein).

Although less constrained by stratigraphic data, the change in style of the tectonic deformations in the perityrrhenian arcs seem to mirror the changes in the stress pattern that occurred in the Tyrrhenian Sea. At any rate, also after middle Pliocene, deformations and unconformities/hiatuses in sedimentary sequences 
occurring in the perityrrhenian orogens seem to correspond again to end of rifting, oceanic crust emplacement, and to later strong subsidence in the Tyrrhenian Basin (Fig. 4).

\section{DISCUSSION AND CONCLUSIONS}

The data and hypotheses previously discussed point to a rather complicated evolution for the Tyrrhenian Sea and its peripheral orogens. The Tyrrhenian basin developed within a domain already deformed during several tectonic phases spanning from Upper Cretaceous to Tortonian times. The basin was generated by a number of discrete rifting events leading to two small oceanic domains, in a pattern of changing subsidence rates, extensional stresses, and volcanism. Meantime (since upper Tortonian), the perityrrhenian orogenic systems of Italy and Sicily were further deformed.

At a large scale, these deformations are recorded as rotations of orogen segments and of thrust units (anticlockwise in the Southern Apennines and clockwise in the Sicilian Maghrebids). At a smaller scale, we observe thrust and wrench faults affecting the post-upper Tortonian sequences of the external chains/foredeeps, as well as normal listric and wrench faults affecting and conditioning the deposition of sedimentary sequences in the internal portions of the chains ("postorogenic" basins).

The "discontinuous" evolution of these deformed sectors is recorded and dated by unconformities/hiatuses occurring, roughly at the same stratigraphic level, within the post-Tortonian sequences and subdividing them into sedimentary cycles. How much of this cyclicity is due to global sea level changes or to coastal onlap (Vail and Mitchum, 1977), and how much is due to tectonic causes is still an open question (Ricci Lucchi, 1986). In a region of very strong compressional deformations, with horizontal throws exceeding tens of kilometers, such as the Apennines during upper Neogene and Quaternary, we may safely assume that tectonism must be an important cause. Its effects are probably imprinted by eustatic sea level changes, especially by the large and frequent oscillations that occurred during the Pleistocene glacial/interglacial cycles.

A fair temporal correlation can be observed between deformational events in the Tyrrhenian "tectonic source area" and cyclic development of deposition and deformation in its peripheral orogens or "tectonic accumulation areas" (Figs. 2-4). A particularly good correlation seems to exist between syn-rift in-

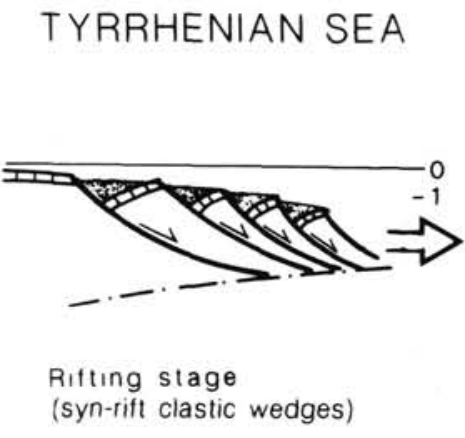

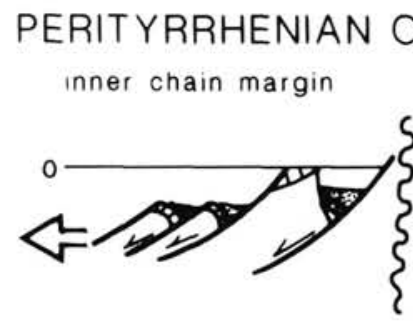

Sedimentary cycle in "postorogenic"basins

\section{OROGENS (N-APENNINES CASE)}

A

outer chain foredeep loreland

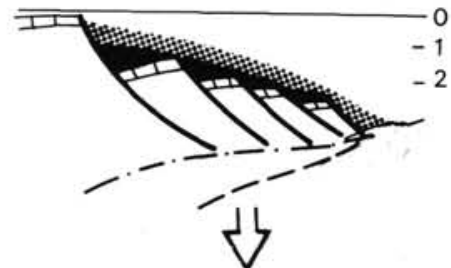

Drifting stage and post-rift subsidence

(break-up unconformity and oceanic crust)

B

Dre-rift, pre-thrust
sequences

$$
\text { sequences }
$$
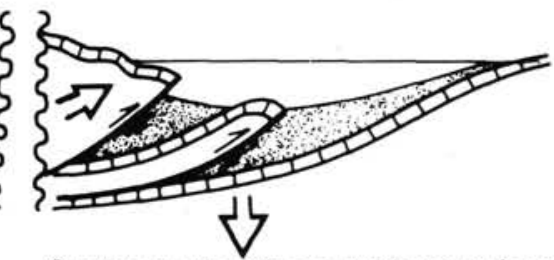

Continuous thrusting. subsidence in foredeep and piggy-back basins (syn-thrust clastic wedges)

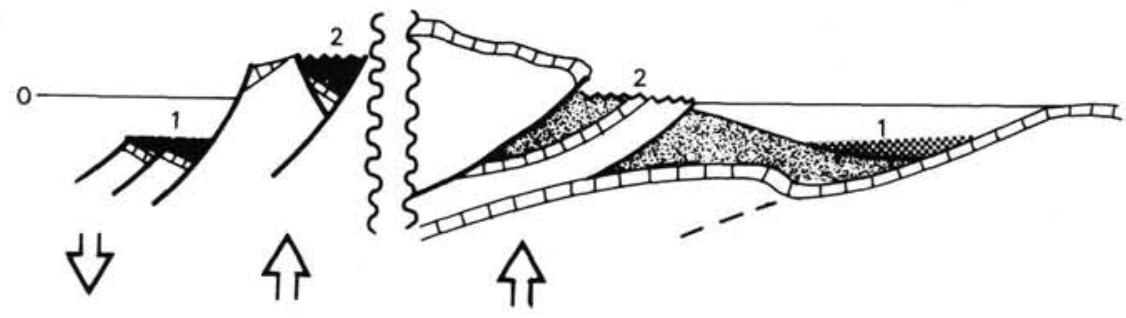

Subsidence and unconformities(1)or uplift and hiatuses (2) in "posiorogenic"cycles

Chain and thrust-belt uplift with niatuses(2) and unconformities(1) Outward migration of foredeep axis -' Possible locus of development of a future thrust fault

Figure 6. An idealized sketch (not to scale) representing two stages of development of the Tyrrhenian Basin and the deformations co-occurring in the peripheral orogens (Northern Apennines). A. Rifting stage in the Tyrrhenian Sea, with horizontal extension and deposition of clastic wedges in half-grabens. The same processes occur in the half-grabens of the internal portions of the chain (e.g., Tuscany) while in the external regions continuous shortening by thrusting and wedge-shaped sedimentary cycles develop in foredeep and satellite basins. B. Accelerated subsidence in the Tyrrhenian Basin, essentially a vertical process, is accompanied in the peripheral orogens by uplift and/or subsidence, modifying the basins morphology and inducing hiatuses and/or unconformities in the sedimentary deposits. These events could have a rather important component of isostatic readjustment of disequilibria formerly induced by horizontal movements, differential loading by thrusts, and differential lateral densities (e.g., Sabadini and Spada, 1988). Eustatic sea level changes may further contribute to cyclicity. Deformations attributable to the drifting stages in the Tyrrhenian Sea are not reported in this sketch. 
tervals in the Tyrrhenian Sea and periods of continuous subsidence and deposition at the internal and external borders of the orogens. In the latter areas, this continuity of subsidence is reflected by the deposition of a sedimentary cycle both in the "postorogenic" basins of the graben/half-graben systems of the internal chains and in the foredeeps/satellite basins of the external portions (Fig. 6A). As for the syn-rift wedges of the Tyrrhenian Sea, most of these cycles are geometrically arranged in clastic wedges (Ricci Lucchi, 1986), which are again syn-rift in the internal chains, and syn-thrust in the external ones. This suggests a compensation between the crustal stretching in the Tyrrhenian Sea and inner chains (or eastern conjugate margin of the developing basin) and the thrusting, with crustal shortening, in the outer borders of the chains.

The correlation between hiatuses/unconformities in the chains and deformational events in the Tyrrhenian Sea is less straightforward, since the former correspond to the either end of rifting (and start of drifting) or to accelerated subsidence of portions of the basin (Figs. 2-4). Hiatuses and unconformities correlated to drifting may represent periods of rotations and shortening of large-scale elements, mainly in the southern portions of the orogens (Southern Apennines, Calabria), facing the most thinned portion of the Tyrrhenian Basin. Some sedimentation breaks may, however, also be largely imputed to causes having a strong vertical component, such as, for instance, isostatic reequilibration. In this hypothesis we could try to relate the episodes of accelerated subsidence in the Tyrrhenian Sea, accompanying and following the emplacement of discrete domains of oceanic crust, to either strong subsidence or strong uplift in the chains and their borders, thus causing hiatuses or unconformities in the sedimentary record of areas just extended or shortened during the periods of rifting and thrusting (Fig. 6B).

In the refined stratigraphic frame available for the Mediterranean upper Neogene, we can infer that each recorded postTortonian unconformity or hiatus does not exceed a duration of a few hundred thousand years, while continuous sedimentation can span more than $1 \mathrm{Ma}$. The temporal order of magnitude of sedimentation breaks fits well with an almost complete isostatic readjustment of the masses deformed during the episodes of rifting, drifting, and thrusting. Such reequilibration is possibly also imprinted by eustatic sea level changes.

As regards the causes of modifications, in space and in time, of stress pattern and of loci of oceanic crust development, we have to remember that the whole region appears ruled by a pullarc regime in the sense of Laubscher (1988), at least since upper Tortonian time. This means that extension in the basin and coeval generalized subsidence are related to the pull effect exerted by a retreating lithospheric slab presently recorded only under the southeastern Tyrrhenian Sea (passive subduction of Ritsema, 1979; see also Malinverno and Ryan, 1986). The evolutionary changes in the Tyrrhenian Sea may then be connected to changes with time ( $=$ with depth) of the configuration of this lithospheric slab (Ritsema, 1979). Its complex shape results from the interactions between the major plates acting in the central Mediterranean and the "locking effect" caused by the presence of rooted continental areas and/or smaller plates.

\section{ACKNOWLEDGMENTS}

The paper was greatly improved by critical reading and reviews by $\mathrm{A}$. Castellarin, R. Gelati, J. Mascle, G. B. Vai., and by stimulating discussions with R. Capozzi, E. Patacca, D. Rio, P. Scandone, and R. Sprovieri. Work supported by M.P.I. $40 \%$ and $60 \%$ grants (1988) to R. Sartori.

\section{REFERENCES}

Amodio-Morelli, M., Bonardi, G., Dietrich, D., Giunta, G., Ippolito, F., Lorenzoni, S., Perrone, V., Picarretta, V., Russo, M., Scandone,
P., Zanettin, E., and Zuppetta, A., 1976. L'arco calabro-peloritano nell'orogene appenninico-maghrebide. Mem. Soc. Geol. It., 17:160.

Bally, A. W., Burbi, L., Cooper, C., and Ghelardoni, R., 1986. Balanced sections and seismic reflection profiles across the Central Apennines. Mem. Soc. Geol. It., 35:257-310.

Barberi, F., Bizouard, H., Capaldi, G., Ferrara, G., Gasparini, P., Innocenti, F., Joron, J. L., Lambret, B., Treuil, M., and Allegre, C., 1978. Age and nature of basalts from the Tyrrhenian abyssal plain. In Hsü, K. J., Montadert, L., et al., Init. Repts. DSDP, 42, Pt. 1: Washington (U.S. Govt. Printing Office), 509-516.

Barberi, F., and Cherchi, A., 1981. Evolution du Mèsozoique-Cenozoique de la Sardaigne: aspects stratigraphiques et volcanologiques et leurs signification structurale. Rapp. Proc. Verb. CIESM, 27:165170.

Barone, A., Fabbri, A., Rossi, S., and Sartori, R., 1982. Geological structure and evolution of the marine areas adjacent to the Calabrian arc. Earth Evol. Sci., 3:207-221.

Bartolini, C., Bernini, M., Carloni, G. C., Costantini, A., Federici, P. R., Gasperi, G., Lazzarotto, A., Marchetti, G., Mazzanti, R., Papani, G., Pranzini, G., Rau, A., Sandrelli, F., Vercesi, P. L., Castaldini, D., and Francavilla, F., 1983. Carta neotettonica dell'Appennino settentrionale. Note illustrative. Boll. Soc. Geol. It., 101:523-549.

Beccaluva, L., Civetta, L., Macciotta, G., and Ricci, C. A., 1985a. Geochronology in Sardinia: results and problems. Rend. Soc. It. Miner. Petr., 40:57-72.

Beccaluva, L., Gabbianelli, G., Lucchini, F., Rossi, P. L., and Savelli, C., 1985b. Petrology and K/Ar age of volcanics dredged from the Eolian seamounts: implications for geodynamic evolution of the southern Tyrrhenian basin. Earth Planet. Sci. Lett., 74:187-208.

Boccaletti, M., Coli, M., Decandia, F. A., Giannini, E., and Lazzarotto, A., 1980. Evoluzione dell'Appennino settentrionale secondo un nuovo modello strutturale. Mem. Soc. Geol. It., 21:359-373.

Boccaletti, M., Calamita, F., Centamore, E., Chiocchini, U., Deiana, G., Moratti, G., Micarelli, A., and Potetti, M., 1986a. Evoluzione dell'Appennino tosco-umbro-marchigiano durante il Neogene. $G$. Geol., 48:227-233.

Boccaletti, M., Tortorici, L., and Ferrini, G. L., 1986b. The Calabrian Arc in the frame of the evolution of the Tyrrhenian Basin. G. Geol., 48:113-120.

Bolis, G., Capelli, V., and Marinelli, M., 1981. Aeromagnetic data of the Italian area: instrumental to a better comprehension of the basement main characteristic in Italy. AGIP-EAEG (43rd meeting), Venezia.

Bouillin, J. P., Durand Delga, M., and Olivier, P., 1986. Betic-Rifian and Tyrrhenian arcs: distinctive feature genesis and development stages. In Wezel, F. C. (Ed.), The origin of arcs. Developments in Geotectonics, Amsterdam (Elsevier), 19:218-304.

Bourrouilh, R., 1973. Stratigraphie, sedimentologie et tectonique de l'ile de Minorque et du Nord-Est de Majorque (Baleares) (Thesis). Univ. Paris.

Calamita, F., and Deiana, G., 1988. The arcuate shape of the UmbriaMarche-Sabina Apennines (Central Italy). Tectonophysics, 146:139147.

Calanchi, N., Colantoni, P., Gabbianelli, G., Rossi, P. L., and Serri, G., 1984. Physiography of Anchise seamount and of the submarine part of Ustica Island (south Tyrrhenian): petrochemistry of dredged volcanic rocks and geochemical characteristics of their mantle sources. Miner. Petrogr. Acta, 28:215-241.

Carbone, S., Grasso, M., and Lentini, F., 1982. Considerazioni sull'evoluzione geodinamica della Sicilia sud-orientale dal Cretaceo al Quaternario. Mem. Soc. Geol. It., 24:367-386.

Carmignani, L., Giglia, G., and Kligfield, R., 1978. Structural evolution of the Apuane Alps: an example of continental margin deformation in the Northern Apennines, Italy. J. Geol., 86:487-504.

Carrara, C., and Serva, L., 1982. Significato paleotettonico delle porzioni conglomeratiche di formazioni terrigene dell'Appennino meridionale. Mem. Soc. Geol. It., 24:209-216.

Casnedi, R., Crescenti, U., and Tonna, M., 1982. Evoluzione della avanfossa adriatica meridionale del Plio-Pleistocene, sulla base di dati del sottosuolo. Mem. Soc. Geol. It., 24:243-260.

Castellarin, A., Colacicchi, R., and Praturlon, A., 1978. Fasi distensive, trascorrenze e sovrascorrimenti lungo la "Linea Ancona-Anzio", dal Lias medio al Pliocene. Geol. Romana, 17:161-189. 
Castellarin, A., and Vai, G. B., 1986. South alpine versus Po Plain Apenninic Arcs. In Wezel, F. C. (Ed.), The origin of arcs. Developments in Geotectonics, Amsterdam (Elsevier), 19:253-280.

Catalano, R., and D'Argenio, B., (Eds.), 1982. Guida alla geologia della Sicilia occidentale. Soc. Geol. It. Guideb. Geol. Reg.

Catalano, R., D'Argenio, B., and Nicolich, R., 1988. From Sardinia Channel to Sicily Straits: stratigraphy and structures. Comunication presented at Europ. Geophys. Soc., XIII General Assembly, Bologna 21-25 March 1988.

Cherchi, A., and Montadert, L., 1982. Oligo-Miocene rift of Sardinia and the early history of the western Mediterranean basin. Nature, 298:736-737.

Ciaranfi, N., Cinque, A., Lambiase, S., Pieri, P., Rapisardi, L., Ricchetti, G., Sgrosso, I., and Tortorici, L., 1983. Proposta di zonazione sismotettonica dell'Italia meridionale. Rend. Soc. Geol. It., 4: 493-496.

Colantoni, P., Fabbri, A., Gallignani, P., Sartori, R., and Rehault, J. P., 1981a. Carta litologica e stratigrafica dei mari italiani (1: 1,500,000). Firenze (Litografia Artistica Cartografica).

Colantoni, P., Lucchini, F., Rossi, P. L., Sartori, R., and Savelli, C., 1981b. The Palinuro Volcano and magmatism of the southeastern Tyrrhenian Sea (Mediterranean). Mar. Geol., 39:M1-M12.

Curzi, P., Fornos, J., Mauffret, A., Sartori, R., Serra, J., Zitellini, N., Borsetti, A. M., Canals, M., Castellarin, A., Pomar, L., Rossi, P. L., and Sabat, F., 1985. The South-Balearic margin (Menorca Rise): objectives and preliminary results of the cruise BAL 84 . Rend. Soc. Geol. It., 8:91-96.

Dal Piaz, G. V., Del Moro, A., Di Sabatino, B., Sartori, R., and Savelli, C., 1983. Geologia del Monte Flavio Gioia (Tirreno centrale). Mem. Sci. Geol., Padova, 35:429-452.

D'Argenio, B., Pescatore, T., and Scandone, P., 1975. Structural pattern of the Campania-Lucania Apennines. In Ogniben, L., et al. (Eds.), Structural Model of Italy, Quad. Ric. Sci., 90:313-327.

Decima, A., and Wezel, F. C., 1973. Late Miocene evaporites of the central Sicilian Basin. In Ryan, W.B.F., Hsü, K. J., et al. Init. Repts. DSDP, 13, Washington (U.S. Govt. Printing Office), 1234-1239.

Di Nocera, S., Ortolani, F., Torre, M., and Russo B., 1979. Caratteristiche stratigrafiche e paleoambientali dei depositi altomiocenici nella zona di Falconara Albanese (Catena Costiera Calabra). Boll. Soc. Nat. Napoli, 83:1-29.

Duschenes, J., Sinha, M. C., and Louden, K. E., 1986. A seismic refraction experiments in the Tyrrhenian Sea. Geophys. J. R. Astron. Soc., 85:139-160.

Edel, J. B., 1980. Etude paléomagnetique en Sardaigne. Conséquences pour la géodynamique de la Méditerranée occidentale (Thesis). Univ. Strasbourg.

Elter, P., 1980. Apennin Septentrional. Introduction a la gèologie gènerale d'Italie, Rend. Soc. It. Mineral. Petrol., 27-31.

Fabbri, A., and Curzi, P., 1979. The Messinian of the Tyrrhenian Sea: seismic evidence and dynamic implication. G. Geol., 43:215-248.

Fabbri, A., Gallignani, P., and Zitellini, N., 1981. Geologic evolution of the peri-Tyrrhenian sedimentary basins of Mediterranean margins. In Wezel, F. C. (Ed.), Sedimentary Basins of Mediterranean Margins. Bologna (Tecnoprint), 101-126.

Fabbri, A., Ghisetti, F., and Vezzani, L., 1980. The Peloritani-Calabria range and the Gioia Basin in the Calabrian arc (Southern Italy): relationships between land and marine data. Geol. Romana, 19:131150.

Fanucci, F., 1986. Evolution stratigraphique de la region du Golfe de Genes depuis l'Eocene superieur. Mem. Soc. Geol. It., 36:19-30.

Filin, A. M., Gorodnizkij, A. M., Palschin, N. A., Popov, K. V., Schischkina, N. A., and Schreider, A. A., in press. Nuovi dati sulla struttura del campo di anomalia magnetica sulle montagne sottomarine Vercelli e Vavilov (Mar Tirreno), (in Russian).

Finetti, I., and Del Ben, A., 1986. Geophysical study of the Tyrrhenian opening. Boll. Geofis. Teor. Appl., 28:75-155.

Gasparini, C., Iannaccone, G., Scandone, P., and Scarpa, R., 1982. Seismotectonics of the Calabrian Arc. Tectonophysics, 84:267-286.

Gennesseaux, M., Rehault, J. P., Thomas, B., Colantoni, P., Fabbri, A., Lepvrier, C., Mascle, G., Mauffret, A., Polino, R., Robin, C., and Vanney, J. R., 1986. Resultats des plongees en submersible Cyana sur le blocs continentaux bascules et le volcan Vavilov (mer Tyrrhenienne centrale). C. R. Acad. Sci. Ser. 2, 12:785-792.
Ghisetti, F., and Vezzani, L., 1982. The recent deformation mechanism of the Calabrian arc. Earth Evol. Sci., 3:197-206.

Giglia, G., 1974. L'insieme Corsica-Sardegna e i suoi rapporti con l'Appennino settentrionale: rassegna di dati cronologici e strutturali. Rend. Sem. Fac. Sci. Cagliari, Suppl. 3:245-275.

Iaccarino, S., and Papani, G., 1979. Il Messiniano dell'Appennino settentrionale dalla val d'Arda alla val Secchia: stratigrafia e rapporti con il substrato e il Pliocene. Volume In Memoria di S. Venzo, STEP (Parma), 15-46.

Incoronato, A., and Nardi, G., 1987. Paleomagnetic evidences for a peri-Tyrrhenian orocline. Atti Acc. Naz. Lincei, Roma, (preprint), 65-76.

Kastens, K. A., Mascle, J., et al., 1987. Proc. ODP, Init. Repts., 107: College Station, TX (Ocean Drilling Program).

Kastens, K. A., et al., 1988. ODP Leg 107 in the Tyrrhenian Sea: insights into passive margin and backarc basin evolution. Geol. Soc. Am. Bull., 100:1140-1156.

Laubscher, H. P., 1988. The arcs of the Western Alps and the Northern Apennines an updated view. Tectonophysics, 146:67-78.

Lavecchia, G., Minelli, G., and Pialli, G., 1988. The Umbria-Marche arcuate fold belt. Tectonophysics, 146:125-138.

Locardi, E., 1986. Tyrrhenian volcanic arcs: volcano-tectonics, petrogenesis and economic aspects. In Wezel, F. C. (Ed.), The origin of arcs. Amsterdam (Elsevier), 351-373.

Malinverno, A., and Ryan, W.B.F., 1986. Extension in the Tyrrhenian Sea and shortening in the Apennines as result of arc migration driven by sinking of the lithosphere. Tectonics, 5:227-245.

Marabini, S., and Vai, G. B., 1985. Analisi di facies e macrotettonica della Vena del Gesso in Romagna. Boll. Soc. Geol. It., 104:21-42.

Marinelli, G., 1975. Magma evolution in Italy. In Squyres, C. H. (Ed.), Geology of Italy. Earth Sci. Soc. Libya, 165-219.

Mostardini, F., and Merlini, S., 1986. Appennino centro-meridionale. Sezioni geologiche e proposta di modello strutturale. AGIP, Milano, $1-53$.

Moussat, E., 1983. Evolution de la Mer Tyrrhenienne centrale et orientale et des ses marges septentrionales en relation avec la neotectonique dans l'arc calabrais (Thesis). Univ. Pierre et Marie Curie, Paris.

Moussat, E., Rehault, J. P., and Fabbri, A., 1986. Rifting et evolution tectono-sedimentaire du Bassin tyrrhenien au cours du Neogene et du Quaternaire. G. Geol., 48:41-62.

Ortolani, F., 1979. Alcune considerazioni sulle fasi tettoniche mioceniche e plioceniche dell'Appennino meridionale. Boll. Soc. Geol. It., 97: 609-616.

Ortolani, F., and Aprile, F., 1977. Struttura profonda dell'Irpinia centrale (Appennino campano). Boll. Soc. Geol. It., 95:903-921.

Parotto, M., and Praturlon, A., 1975. Geological summary of central Apennines. In Ogniben, L., et al. (Eds.) Structural Model of Italy, Quad. Ric. Sci., 90:257-311.

Patacca, E., and Scandone, P., 1987. Tectonic evolution of the outer margin of the Apennines and related foredeep system. Atti Acc. Naz. Lincei, Roma, (preprint), 139-142.

Pieri, M., and Groppi, G., 1981. Subsurface geological structure of the Po Plain. Geodinamica, C.N.R., 1-23.

Pomar, L., Marzo, M., and Bardon, A., 1983. El Terciario de Mallorca. $X$ Congr. Nac., Guia de les excursiones, Menorca, 21-45.

Recq, M., Rehault, J. P., Steinmetz, L., and Fabbri, A., 1984. Amincissement de la croute et accrètion au centre du bassin Tyrrhenien d'après la sismique rèfraction. Mar. Geol., 5:411-428.

Rehault, J. P., 1981. Evolution tectonique et sedimentaire du Bassin Ligure (Mediterranee occidentale) (Thesis). Univ. Pierre et Marie Curie, Paris.

Rehault, J. P., Moussat, E., Mascle, J., and Sartori, R., 1985. Geodynamic evolution of the Tyrrhenian Sea. New data and drilling objectives (ODP Leg 107, Mediterranean). 8th Congr. Reg. Comm. Medit. Neogene Strat., Budapest, 15-22 Sept. 1985. (Abstract)

Ricci Lucchi, F., 1986. The foreland basin system of the Northern Apennines and related clastic wedges: a preliminary outline. G. Geol., 48:165-185.

Ritsema, A. R., 1979. Active or passive subduction at the Calabrian Arc. Geol. en Mijnbouw, 58:127-134.

Rossi, S., and Sartori, R., 1981. A seismic reflection study of the external Calabrian Arc in the Northern Ionian Sea (Eastern Mediterranean). Mar. Geophys. Res., 4:403-426. 
Ryan, W.B.F., Hsü, K. J., et al., 1973. Site 132. In Ryan, W.B.F., Hsü, K. J., et al., Init. Repts. DSDP, Washington (U.S. Govt. Printing Office), 403-464.

Sabadini, R., and Spada, G., 1988. Ground motion and stress accumulation driven by density anomalies in a viscoelastic lithosphere: some results for the Apennines. Geophys. J., 95:463-480.

Sartori, R., 1986. Notes on the geology of the acoustic basement in the Tyrrhenian Sea. Mem. Soc. Geol. It., 36:99-108.

Sartori, R., et al., 1987a. Drillings of ODP leg 107 in the Tyrrhenian Sea: tentative basin evolution compared to deformations in the surrounding chains. Atti Acc. Naz. Lincei, Roma, (preprint), 125-138.

Sartori, R., Mascle, G., and Amaudric Du Chaffaut, S., 1987b. A review of circum-tyrrhenian regional geology. In Kastens, K. A., Mascle, J., et al., 1987. Proc. ODP, Init. Repts,. 107: College Station, Tx (Ocean Drilling Program), 37-63.

Sartori, R., and Scandone, P., 1985. Geological problems in the Tyrrhenian area and planned future research. Second EGT workshop: the southern segment. European Science Foundation, Strasbourg, 221222.

Sartori, R., Sprovieri, R., Rio, D., and ODP Leg 107 Scientific Party, 1986. Faunal evidence of middle Pliocene strong subsidence in the central Tyrrhenian basin. Data from ODP Leg 107. Oceans, Sèance Spec. Soc. Geol. Fr. and Soc. Geol. It., Villefranche sur Mer, 1-3 Dec. 1986. (Abstract)

Savelli, C., 1984. Evoluzione del vulcanismo cenozoico (da $30 \mathrm{MA}$ al presente) nel Mar Tirreno e nelle aree circostanti: ipotesi geocronologica sulle fasi di espansione oceanica. Mem. Soc. Geol. It., 27: 111-119.

Scandone, P., 1982. Structure and evolution of the Calabrian Arc. Earth Evol. Sci., 3:172-179.

Selli, R., 1970. Cenni morfologici generali sul Mar Tirreno. In Selli, R. (Ed.), Ricerche Geologiche Preliminari nel Mar Tirreno, G. Geol., 37:5-24.

, 1974. Appunti sulla geologia del Mar Tirreno. In Paleogeografia del Terziario sardo nell'ambito del Mediterraneo occidentale. Rend. Semin. Fac. Sci. Univ. Cagliari, Suppl. 3:327-351.

1981. Thoughts on the geology of the Mediterranean region. In Wezel, F. C. (Ed.), Sedimentary Basins of Mediterranean Margins. Bologna (Tecnoprint), 489-501.
Selli, R., and Fabbri, A., 1971. Tyrrhenian: a Pliocene deep sea. Rend. Atti Accad. Naz. Lincei, 50:580-592.

Selli, R., Lucchini, F., Rossi, P.L., Savelli, C., and del Monte, M., 1977. Dati geologici, petrochimici e radiometrici sui vulcani centrotirrenici. G. Geol., 42:221-246.

Shipboard Scientific Party, 1978. Site 373: Tyrrhenian Basin. In Hsü, K. J., Montadert, L., et al., Init. Repts. DSDP, 42 (Pt. 1): Washington (U.S. Govt. Printing Office), 151-174.

Steinmetz, L., Ferrucci, F., Hirn, A., Morelli, C., and Nicolich, R., 1983. A $550 \mathrm{Km}$ long Moho traverse in the Tyrrhenian Sea from 0.B.S. recorded Pn waves. Geophys. Res. Lett., 10:428-431.

Thunell, R. C., and Williams, D. F., 1983. The stepwise development of Pliocene-Pleistocene paleoclimatic and paleoceanographic conditions in the Mediterranean: Oxygen isotopic studies of DSDP Sites 125 and 132. Utrecht Micropaleontol. Bull., 30:111-127.

Trincardi, F., and Zitellini, N., 1987. The rifting of the Tyrrhenian Basin. Geom. Letts., 7:1-6.

Vail, P. M., and Mitchum, R. M., 1977. Seismic interpretation and global changes in sea level: an overview. In Payton, C. E. (Ed.), Seismic stratigraphy applications to hydrocarbon exploration. A.A.P.G. Mem., 26:51-56.

Wezel, F. C., 1985. Structural features and basin tectonics of the Tyrrhenian Sea. In Stanley, D. J., and Wezel, F. C. (Eds.), Geological evolution of the Mediterranean Basin. New York (Springer Verlag), 153194.

Winnock, E., 1981. Structure du bloc pélagien. In Wezel, F. C. (Ed.), Sedimentary basins of the Mediterranean margins. Bologna (Tecnoprint), $445-464$.

Zitellini, N., Trincardi, F., Marani, M., and Fabbri, A., 1986. Neogene tectonics of the Northern Tyrrhenian Sea. G. Geol., 48:25-40.

Date of initial receipt: 5 July 1988

Date of acceptance: 4 April 1989

Ms 107B-183 